\title{
Cornelius Sinclair's Odyssey: Freedom, Slavery, and Freedom Again in the Old South
}

\author{
Judson E. Crump \\ Unaffiliated Authors - Independent, judsonecrump@gmail.com \\ Alfred L. Brophy \\ University of Alabama - School of Law, abrophy@law.ua.edu
}

Follow this and additional works at: https://scholarship.law.ua.edu/fac_working_papers

\section{Recommended Citation}

Judson E. Crump \& Alfred L. Brophy, Cornelius Sinclair's Odyssey: Freedom, Slavery, and Freedom Again in the Old South, (2014).

Available at: https://scholarship.law.ua.edu/fac_working_papers/23

This Working Paper is brought to you for free and open access by the Faculty Scholarship at Alabama Law Scholarly Commons. It has been accepted for inclusion in Working Papers by an authorized administrator of Alabama Law Scholarly Commons. 


\title{
Twenty-One Months a Slave: Cornelius Sinclair's Odyssey
}

\author{
Judson Crump ${ }^{1}$ and Alfred L. Brophy ${ }^{2}$
}

In August 1825 several free, young black people were enticed onto a ship in the Delaware River along the Philadelphia waterfront. Thus began their descent to the heart of the old South. They were kidnapped and held aboard a ship destined for a stop somewhere near Cape Henlopen, Delaware. Some days later they were carried by wagon to Maryland's eastern shore and another ship took them further south. They walked across Georgia and into Alabama. One young man, Cornelius Sinclair, was sold in Tuscaloosa. He was a free person converted into a slave.

But that was not the end. A local minister helped Sinclair by filing a lawsuit to ask for his freedom. A slave-owning judge presided over the trial that freed Sinclair. The newly freed Sinclair returned to Philadelphia to face down one of his kidnappers.

Sinclair's story is one of epic proportions. It is a nineteenth century version of the Odyssey. And while Sinclair's journey took fewer years than Odysseus', Sinclair traveled far. This story is one of the dark evil in human hearts and also of the triumph, even if in greatly circumscribed fashion, of the rule of law. It is a story of a most unexpected turn in a legal system dedicated to the maintenance of the system of slavery.

While there has been some previous discussion of Sinclair's case, that story has been told only briefly and exclusively from the perspective of the anti-slavery press and records in Philadelphia. This is the first time that the Tuscaloosa jury trial has been told, or even known. And in this case study one can see the difficulty that southern jurists, slave-owners, and litigants had in dealing with the central tendency of the slave law in contrast with considerations of humanity and justice. There might have been some content, even if extremely limited, to the rule of law.

1 Judson E. Crump, PC, Mobile, Alabama.

2 Judge John J. Parker Distinguished Professor of Law, University of North Carolina. We would like to thank Andrew Fede, Daniel M. Filler, Peter Hoffer, Dana Remus, and Sarah N. Roth for their comments, as well as the staff of the Tuscaloosa County Court and the librarians at the Historical Society of Pennsylvania, the Hoole Special Collections Library at the University of Alabama, the North Carolina State Archives, the Southern History Collection at the University of North Carolina, Wake Forest University’s Z. Smith Reynolds Library Special Collections, and Washington and Lee's Leyburn Library Special Collections. We would also like to thank Elizabeth Carroll and Christopher Dwight for their research assistance in far-flung archives. 


\section{Cornelius Sinclair's Odyssey:}

Freedom, Slavery, and Freedom Again in the Old South

1. The Kidnapping 3

2. Redemption: "in the cause of humanity" 8

3. Interpreting the Tuscaloosa Freedom Suit 24

A. The Central Tendency of Southern Slave Law 25

B. Questioning the Boundaries of Southern Law 31

C. Sinclair's Odyssey and the Meaning of the Rule of Law 35

4. The Return: Epilogue $\quad 54$

Table 1. Timeline of Cornelius Sinclair's Odyssey 56 


\section{The Kidnapping}

On August 5, 1825 Cornelius Sinclair went looking for work along the Philadelphia waterfront. He met a man with the improbable name of John Smith, who offered him work unloading melons and peaches from a ship in the harbor. Cornelius accepted the offer, followed Smith to a little boat on the shore, got in, and the two of them paddled out to the sloop. ${ }^{3}$ Thus began an odyssey that took him more than a thousand miles away from home, to the heart of the slave-owning south, and eventually back to freedom.

When he stepped aboard the ship, Sinclair found no melons to be handled. Instead, several men he did not recognize assaulted him, bound him in shackles, and locked him in the vessel's cargo hold. Three other young African American boys were already captive there. The oldest was a fifteen-year-old boy named Samuel Scomp, who was an indentured servant who had fled his master in New Jersey. ${ }^{4}$ The others were Enos Tillman (or perhaps Tilghman), a nineyear-old boy who had been an apprentice, and another small boy named Alexander Manlove. The little ones had been there since the day before.

\footnotetext{
${ }^{3}$ Cornelius Sinclair by his best friend Joshua Boucher v. James Paul, Chancery Docket Record Book, 1825-27, Tuscaloosa County Circuit Court, at 181 (available at the Tuscaloosa County Courthouse).

${ }^{4}$ Narrative of Samuel Scomp, 1 THE AFRICAN OBSERVER 39-41 (May 1827) (Scomp's deposition was sworn on June 30, 1826). This deposition was reprinted and is one of the few pieces of this story that is known to historians. See Samuel Scomp, Deposition to the Mayor's Office of the City of Philadelphia, June 30, 1826, reprinted in SLAVE TESTIMONy: Two Centuries OF LeTters, SPEECHES, INTERVIEWS, AND AUTOBIOGRAPHIES 178-81 (John W. Blassingame, ed., 1977). Sinclair's kidnapping was part of a larger story, which is told by Julie Winch. See Julie Winch, Philadelphia and The Other Underground Railroad, 111 PA. MAG. HIST. \& BIO. 3 (1987).
} 
Or maybe Sinclair's odyssey began in a slightly different way. When it had ended, Sinclair told a jury in Philadelphia that Smith had offered him work but that instead of agreeing immediately he followed Smith from around Front Street for several blocks to the New Market at South and Second Streets, where he was overcome by a white man. That man held some kind of pliable plaster over his mouth so that no one would hear him screaming, then pulled him into a covered wagon. Several miles away, they loaded him onto a boat near Philadelphia. ${ }^{5}$

However the initial kidnapping took place, Sinclair and the others were held on a boat in the Delaware River. There they remained for the rest of that day, the darkness of their prison only interrupted to see one more fellow, captured by a similar ruse, thrown in with them. ${ }^{6} \mathrm{He}$ was a 16-year old chimney sweep named Joe Johnson. ${ }^{7}$ That was the last Johnson would ever see of Philadelphia. A short time later, a man the others called Collins came down and threatened to cut the throats of any of the boys who made noise. ${ }^{8}$ At night, the anchor was drawn and the sloop sailed down the Delaware River. ${ }^{9}$ They were on the water for about a week. Eventually they saw the lighthouse at Cape Henlopen. They landed somewhere on the southern Delaware coast, about twenty miles from the house of their kidnapper, a man who also was named Joe

\footnotetext{
${ }^{5}$ Kidnapping, FreEdOM's Journal, June 22, 1827, at 3 (reprinting story from the Philadelphia Daily Advertiser).

6 Sinclair Complaint, supra note 3.

${ }^{7}$ Scomp Deposition, supra note 4, at 40. The stories of Scomp and Sinclair differ slightly in that Scomp recalls Sinclair being the last one brought on board, while Sinclair recalled Joe Johnson coming after him. See Sinclair Complaint, supra note 3 .

8 Scomp Deposition, supra note 4 , at 40.

${ }^{9}$ See The Narrative of Peter Hook, AFRICAN OBSERVER 43, 44 (May 1827) (reporting that Hook, who was kidnapped a few months before Sinclair, sailed past the capes where the captives "saw the light house"). It is likely that the sloop that took Sinclair down the Delaware followed the same route.
} 
Johnson. The slavers took the boys off the boat until after sundown, at which point they traded their leg chains for neck-ropes. And so they were

marched through marshes, cornfield, and brushwood, until they were taken up by a carriage driven by Joe Johnson, and carried to his house; they were confined in a garret [attic] there in irons 24 hours, then carried to Jesse Cannon's on a Sunday night, by him (Cannon) and Ebenezer F. Johnson; this was the first time the boys ever saw Ebenezer, they were kept at Jesse Cannon's about a week in irons in a garret. On a Saturday night, they were put into a wagon with Mary Fisher, (and another woman who said she was a slave named Maria Neal.) Mary Fisher declared she was a free woman, had been kidnapped, and carried to Patty Cannon's....

They ended up at the house of Patty Cannon, the matriarch of a clan of thugs who lived in blatant defiance of the law. The Cannon-Johnson gang operated from the village of Johnson's Crossroads on the Maryland-Delaware border, at a place now known as Reliance, Delaware. ${ }^{11}$ Mrs. Cannon's notorious life inspired decades of storytelling by later authors fascinated by the notion of a cruel and ruthless female crime boss. ${ }^{12}$ A shocking variety of odious misdeeds are alleged to have been committed either by Cannon or under her auspice: she poisoned her husband; when a slave child's crying annoyed her, she threw the baby into a fire; one slave trader who made the mistake of having too much money on him when coming to buy some of her human captives was never seen again. ${ }^{13}$ The possibly apocryphal stories hint at the role that

\footnotetext{
10 Scomp Deposition, supra note 4 , at 40.

11 Joseph Watson to David Holmes and J. E. Davis, of Natchez, Jan 20, 1827, reprinted in Kidnapping, 1 AFRICAN

OBSERVER 37, 45 (May 1827) (giving some of the details of the kidnappers).

12 See George Alfred Townsend, The Entailed Hat, or Patty Cannon’s Times (New York, Harper \& Brothers 1884).

13 JOHN H. K. SHANNAHAN, TALES OF OLD MARYLAND: HistORY AND ROMANCE ON THE EASTERN SHORE OF MARYLAND 65 (Baltimore, Meyer \& Thalheimer 1907).
} 
gothic tales of intrigue captured the public imagination. A biography printed in 1841 makes Patty Canon's story out to be a gothic tale of viciousness and inhumanity so characteristic of the fiction of the era. ${ }^{14}$ When Philadelphia's mayor Joseph Watson wrote about the "mazes of this infernal plot" ${ }^{15}$ his language was also borrowed from the gothic tales of intrigue, which Edgar Allen Poe and George Lippard would soon make famous. ${ }^{16}$ Eventually, at least one of these crimes landed her in jail, where she died while awaiting her trial for murder. ${ }^{17}$

About a week after they were brought to Patty Cannon's property at Johnson's Crossroads, in south western Delaware, the victims saw "John Smith" again. He drove them to the coast, whence they were again loaded onto a small sailing vessel. ${ }^{18}$ The men, women, and children needed no sextant or compass to know where they were going. They were headed into the South, into slavery.

Of the precise course the young captives took through the undeveloped South, we know little. Departing from Patty Cannon's, the children were loaded onto "a larger sloop," and then sailed southward. One of the captives later estimated their second sea voyage to have been a week. Reckoning of time for one locked in near total dark must have been difficult, and the

${ }^{14} I d$.

15 Joseph Watson to David Holmes and J. E. Davis, of Natchez, Jan 20, 1827, reprinted in Kidnapping, 1 AFRICAN OBSERVER 37, 45 (May 1827).

${ }^{16}$ DAVID S. REYNOLDS, BENEATH THE AMERICAN RENAISSANCE: THE SUBVERSIVE IMAGINATION IN THE AGE OF EMERSON AND MELVILle 216 (1988) (discussing George Lippard); id. at 249-50 (discussing Poe and gothic crime stories).

${ }^{17}$ NARRATIVE AND CONFESSIONS OF LUCRETIA P. CANNON 10 (New York, n.p. 1841).

${ }^{18}$ Scomp Deposition, supra note 4 , at 40 . 
victims may not have been too concerned at the time with counting the days. Then again, maybe they were.

They landed at some unknown spot and there began the most onerous part of their odyssey: a march of at least six hundred miles through the woods and fields of the barely-settled South. What we do know is that it was a brutally long, slow, and demoralizing trek. They embarked in late August or early September. The Johnsons had a wagon pulled by horses, and the two youngest captives were usually allowed to sit atop the wagon. Cornelius, Samuel, and Joe, however, walked, without shoes. "[W]hen they complained of sore feet and being unable to travel, they were most cruelly flogged," Scomp reported. ${ }^{19}$ The three older boys were beaten the most often. ${ }^{20}$ At one point, Scomp attempted an escape while in the Choctaw Nation, which was then limited to west-central Alabama, ${ }^{21}$ but was captured by a Native American man and returned to Ebenezer Johnson, "who flogged him with a hand saw and hickories in a most dreadful manner."22 As before, they moved primarily at night, bound by neck-ropes and in fear of being shot. When the sun began to show over the trees, they were chained again and camped somewhere off the beaten path. ${ }^{23}$

\footnotetext{
${ }^{19}$ Scomp Deposition, supra note 4 , at 40.

${ }^{20} I d$.

21 After 1818, the only land in Alabama that remained in Choctaw control was in west-central Alabama. That was finally ceded to the United States in the treaty of Dancing Rabbit Creek in 1830. See Clara SUE KIDWELL, Choctaws And Missionaries IN Mississippi, 1818-1918 164 (1995); Greg O'BriEn, ChOCTAWs IN A
} REVOLUTIONARY AGE, 1750-1830 (2002).

22 Scomp Deposition, supra note 4, at 40.

${ }^{23} I d$. 
Scomp later estimated that they walked thirty miles each day, but their progress was slowed by various delays. In addition to the layovers at Joe Johnson's house and Patty Cannon's, the seagoing portions of the voyage were slow, and the party also stopped for several weeks in some sort of 'safe house' apparently owned by Ebenezer Johnson "near a small town called Ashville, within 16 miles of the Cherokee nation, in southern Alabama." ${ }^{24}$ The weather was turning cold and this caused further hardship for the poorly clothed captives. Young Joe Johnson became "frosted in the feet" while walking through Alabama and was thereby disabled. $^{25}$

After hundreds of miles of marching through the woods and fields of the frontier South and Indian territory, barefoot, poorly clothed, roped, fettered, cold, hungry, and beaten, Cornelius Sinclair and the other captives reached Tuscaloosa, Alabama, in October 1825 with their captor Ebenezer Johnson. Sinclair was sold for $\$ 300$ to James Paul, a local tinship whose shop was in the center of Tuscaloosa. ${ }^{26}$ Johnson continued west with the rest of his kidnapped humans, into Mississippi. Only a few months before, Cornelius had been free. Now he was almost a thousand miles from home, enslaved, friendless, with no cause for hope.

Or maybe not.

\footnotetext{
${ }^{24} I d$. at 41. Something is amiss in Scomp's affidavit, because Cherokee territory was in northeastern Alabama. See William G. McLoughlin, Cherokee Renascence in the New Republic (1986). Ashville, Alabama was incorporated in 1822 in St. Clair County, near Cherokee territory. See A Digest Of THE Laws of the State of Alabama title 62, chap. 121, at 846 (Henry Tomlin ed., Cahawba, Ginn and Curtis 1823).

${ }^{25}$ Scomp Deposition, supra note 4, at 41.

${ }^{26}$ Answer of James Paul, Sinclair v. Paul. Cf. Scomp Deposition, supra note 4, at 40 (reporting having overheard that Sinclair was sold for $\$ 400)$.
} 


\section{Redemption: "in the cause of humanity"}

About twenty young people of African descent had disappeared from Philadelphia in the summer of 1825 and their families and friends began to wonder what had happened to them. ${ }^{27}$ In January 1826 some news began to trickle back to Philadelphia of what had happened. A letter arrived in the office of the Joseph Watson, the mayor of Philadelphia, from a lawyer in Rocky Springs Mississippi, John Henderson, with an astonishing story. ${ }^{28}$ Ebenezer Johnston tried to sell three young men and two young women in late December 1825. Rocky Spring, now a ghost town, was then along the Natchez trace, the road from Nashville, Tennessee, to the prosperous town of Natchez. One likely route from Tuscaloosa would have taken Johnson and his captives southwest to Meridian, Mississippi, then on to Jackson, and finally to Rocky Spring. As one potential buyer, James Hamilton, examined the people Johnston was trying to sell, one of them, Samuel Scomp, protested that he was free. Hamilton undertook an investigation. Soon he found the body of a young man in Johnston's wagon. The story emerged that the young man, Joe Johnston, a chimney sweep, had died from beatings just before the party arrived in Rocky Springs. ${ }^{29}$ Joe was beaten frequently; about a day before he died Ebenezer Johnston had beaten his with a cart whip. ${ }^{30}$

\footnotetext{
27 Kidnapping, AFrICAN OBSERVER, May 1827, at 37.

${ }^{28}$ John Henderson to Joseph Watson, January 2, 1826, Watson Papers, Historical Society of Pennsylvania, reprinted in Eric Ledell Smith, Rescuing African American Kidnapping Victims in Philadelphia as Documented in the Joseph Watson Papers, 129 PA. MAG. HIST. \& BIO. 317, 330-32 (2008).

29 Henderson, supra note 28, at 330.

30 Scomp Deposition, supra note 4 , at 41.
} 
Henderson's letter set in motion efforts by Mayor Watson to collect affidavits about the freedom of each of those people. It took several weeks. ${ }^{31}$ Soon, however, Scomp and several other kidnapping victims were on their way to Natchez, then down the Mississippi to New Orleans and thence back to Philadelphia. By the end of June 1826 there were home in Philadelphia, where Scomp gave an extensive affidavit about his kidnaping and redemption. ${ }^{32}$ Some victims were already home, but Sinclair's ordeal was far from over. But at least people in Philadelphia knew his whereabouts, for Henderson's letter to Mayor Watson had news of Sinclair's sale in Tuscaloosa. ${ }^{33}$

Although Scomp and the others were home in Philadelphia by the end of June 1826 the delay suffered by Sinclair was, according to the African Observer, due to the obstinacy of "a Shylock, who having been defeated in endeavoring to smuggle the boy out of the way, most tenaciously insists upon the ounce of flesh according to the bond." ${ }^{\text {"34 }}$ James Paul would not let Sinclair go without a fight, and a long one. Paul's intransigence led to a constellation of four lawsuits.

Even before Scomp and the others had returned to Philadelphia there was a movement to help reclaim Sinclair. In April 1826 two local Methodist ministers, Reverend Robert L. Kennon and Joshua Boucher, located Sinclair and took him from the man who had purchased him back in October, James Paul. We know this because in October of 1826, Paul brought an action against

\footnotetext{
31 Joseph Watson to J.W. Hamilton \& John Henderson, March 10, 1826, Watson Papers, Historical Society of Pennsylvania, reprinted in Smith, supra note 28, at 334-36.

32 Scomp Deposition, supra note 4, at 39-41.

33 Henderson to Watson, supra note 28, at 331.

34 Kidnapping, 1 AFRICAN OBSERVER 37-38 (May 1827).
} 
Kennon and Boucher for trespass and conversion, "to recover damages for the Defendants taking from the Plaintiff his negro male slave named Cornelius on the 17th of April A.D. 1826 and has converted said Boy to their own use to the damage of the Plaintiff One Thousand Dollars therefore he sues \&c."35 Unfortunately, we do not have the benefit of a jury verdict here to inform our appraisal of the facts alleged by Paul. The case was settled before a trial.

During the months between April and October, 1826, Paul was apparently heard by several townsfolk maligning the two men, accusing them publicly of thievery and other misbehaviors. Some of these verbal lacerations were quite personal, and eventually became an annoyance sufficient to incite Boucher and Kennon to each bring suit against Paul for Slander. The February 1827 term of the Tuscaloosa County Court records these two lawsuits, which are identical in substance, the only differences being the names of the plaintiffs (Kennon brought one suit, Boucher the other). The complaint reads:

This action is brought to recover damages of Defendant for slanderous words spoken by him to of and concerning the plaintiff in the presence and hearing of Joshua Boucher \& other good citizens-- "I (meaning the defendant)" [sic] lost two negroes last night \& have reasons to believe that you and Dr. Kennon (meaning the plaintiff) stole them; it is a pretty pass that you have left your religion and turned to kidnapping" (meaning that he the said Boucher \& plaintiff on the day of 1826 [sic] in the presence \& hearing of James Fears \& others to the following purport_- "Kennon (meaning plaintiff) and Boucher stole my negroes" - and also said at an other time - "Kennon (meaning plaintiff) \& Boucher stole two negroes of mine" and other words to same purpose and effect - the said charge of felony will be variously and in the several counts. ${ }^{36}$

The most stinging insult that Paul dealt to Kennon and Boucher is also the most ironic in the context of Sinclair's case: "It is a pretty pass that you have left your religion and turned to

\footnotetext{
35 James Paul v. Robert L. Kennon, Records and Minutes, Common Law, 1826-27, Tuscaloosa County Circuit Court, at 388.

${ }^{36}$ Id. at 235.
} 
kidnapping." Not only does he condemn their restoration of Sinclair's freedom in religious terms, but Paul, the man who bought Cornelius Sinclair from a kidnapper for three hundred dollars, now lamented the loss of his ill-begotten property by libeling Sinclair's rescuers as "kidnappers." It is almost comical.

This case was also settled by the parties before the trial. Unfortunately the details of any settlement agreement are lost. Whether Boucher and Kennon had freed another of Paul's slaves or whether Paul was exaggerating the number of people they freed is unknown. Perhaps both of the complaints were viable actions and the parties simply dropped both of them reciprocally to lessen the costs of litigation. It is very conceivable that Kennon and Boucher founded their slander cases on evidence that Sinclair had indeed been wrongfully kidnapped, and therefore was never the property of Paul, and that as such it would not have been possible for them to "steal" or "kidnap" Sinclair at all. Though we are unable to know at this point whether Kennon and Boucher had formulated a sufficiently solid case to support Sinclair's petition for freedom, we can infer from their willingness to provide Sinclair refuge sufficient to remove him from Paul's possession that they knew him and believed Sinclair's claim that he was not a slave. Paul was not going to be convinced easily, nor was he going to give up his claim on Sinclair without a fight.

At some point in 1826 Boucher had written the mayor asking for help in making Sinclair's case. That letter was never answered; perhaps it was never even received by the Mayor. So in January 1827 Boucher wrote again and pleaded for help. ${ }^{37}$ He reported that he

\footnotetext{
37 Joshua Boucher to Mayor Joseph Watson, January 17, 1827, Joseph Watson Papers, Box 1, Folder 11, Historical Society of Pennsylvania.
} 
was staying in this land of slavery only to prosecute Sinclair's case and that as soon as it was done, he was moving to Ohio. Boucher asked the mayor for a white witness to come to Tuscaloosa before the second Monday in March to appear at trial. ${ }^{38}$ The letter, which was received on February 8,1826 , in Philadelphia, apparently met with quick action by the Mayor. ${ }^{39}$ At any rate, whatever efforts were made at an out of court settlement ultimately failed to resolve the issue of the legitimacy of Sinclair's slavery, so both sides of the dispute had their chance to try the case in court. James Paul may have hoped to trust his luck to a jury with which he had much more common interest than Cornelius Sinclair. In Sinclair's case, the property interest asserted by James Paul was an interest that the jurors knew well. Sinclair and his supporters could rely only the truth of his story as told by a white witness sent from Philadelphia and the depositions from free people who know him in Philadelphia, the skill of his lawyer, and their exhortations to Justice. Indeed, as Mississippi attorney general Richard Stockton wrote, "the provisions of our humane statutes are enforced, and generally at the expense of our fellow citizens." ${ }^{, 40}$ Yet for the jury, the substantial expense of their fellow citizen was inadequate to overcome the truth of Sinclair's claims. Justice was in this case blind, even if it came with a hefty cost in time and money.

How did this happen? Sinclair's freedom was won with the help of his benefactors in Tuscaloosa and Philadelphia. Even his own petition for freedom was brought "by his next friend Joshua Boucher." According to the records, he also had the help of other local men: Robert L.

\footnotetext{
${ }^{38} I d$. at 2 ("I am remaining in this county until the decision of the suit, at which time I shall remove to the state of Ohio.").

39 See Resolution by Philadelphia Select Council, February 8,1827, reprinted in Smith, supra note 28, at 340-41.

40 Letter, Richard Stockton to Mayor Joseph Watson, May 26, 1827, 1 AFRICAN OBSERVER 42.
} 
Kennon and Dennis Dent. ${ }^{41}$ Sinclair's case required a bond of $\$ 1000$ to be posted with the court to insure Paul against any damages occasioned by the loss of Sinclair's service, should a jury find his bondage to have been legitimate. ${ }^{42}$ Also involved for the men who brought Sinclair's case to court were their reputations within the small community. Thus, while Sinclair himself obviously had the most personally at stake in the legal struggle for his freedom, the men who took his case to court also undertook substantial risks themselves.

This leaves open the most important question regarding Sinclair's benefactors: why did they do it? Who were these people and why would they take action for Sinclair? What drove these three (and countless other) people to take upon themselves the strenuous effort demanded by the process of litigating the case of a strange, young, Northerner against fellow local white men? Though it may be met with proper modern skepticism, the short answer is that they set Cornelius Sinclair free because it was the right thing to do. On this, all three of them agreed, though their individual reasons for pursuing the case may have differed.

The first glimpse into the motivations of the men involved in Sinclair's quest for freedom comes from the men themselves. The body of evidence indicates that Joshua Boucher was probably the primary sponsor of the young man's liberation. Boucher told Philadelphia Mayor

\footnotetext{
41 Boucher's letter of January 17, 1827 also mentions a Mr. Gazzan and an unidentified lawyer. See Boucher, supra note 37 , at 1 .

42 Tuscaloosa Chancery Docket, supra note 3, at 184. See also WiLliam EATON, BoOK OF PRACTICAL FORMS: WITH EXPLANATORY NOTES AND REFERENCES TO AUTHORITIES: INTENDED AS A MANUAL TO THE Practising LAWYER In THE StATE OF NoRTh CAROLINA 6-7 (Philadelphia, Lindsay and Blankiston 1854) (providing forms for bond for double the value of a slave when a plaintiff sought replevin of a slave).
} 
Jospeh Watson that he had instigated the lawsuit ${ }^{43}$ and Boucher's name appears alongside that of Cornelius Sinclair in the complaint against Paul. The petition specifically states that at the time of the trial, Sinclair was "staying in the house of a friend," though it does not tell us exactly which of his friends it was.

Joshua Boucher was a Methodist minister. Church records tell us that he arrived at Tuscaloosa's First Methodist Church in 1825, and that his personal views were quite hostile to the institution of slavery. ${ }^{44}$ He was not, however, a Northerner. Boucher was born in 1797 in Lee County, Virginia, and moved with his family to Tennessee in 1815, where his uncle, also Joshua Boucher, was also a prominent Methodist clergyman. Boucher's personal antipathy towards slavery is said to have originated in his relationship with a particularly pious slave owned by his father. ${ }^{45}$ And here we have one facet of the antislavery sentiment as well, pure

\footnotetext{
${ }^{43}$ Boucher to Watson, January 17, 1827, supra note 37 ("James Paul of this place ... has been sued by this boy for his freedom at my instance.”).

${ }^{44}$ James B. Sellers \& Charles Williams Foster, History of First Methodist ChurCh OF TusCaloosa, Alabama 39, 67-72 (1968); Anson West, A History of Methodism in Alabama 324-25 (Nashville, n.p. 1893). West discusses a controversy over the role of ministers and Free Masons that riled the Tuscaloosa Methodist Church, like many other churches in that period, in 1826. One result of this controversy, in which both Boucher and Kennon sided with the Free Masons, was a decline in the Tuscaloosa Methodist church's membership by about onethird. It may be more than a coincidence that this controversy coincided with Boucher's and Kennon's advocacy on behalf of Sinclair. $I d$. at 325-26.

${ }^{45}$ Minutes of the Cincinnati Annual Conference of the Methodist EPiscopal ChuRCh 64 (Cincinnati, R.P. Thompson 1868).
} 
moral fervor. Methodists in the 1820 s, even in the south, were often critical of the institution of slavery. $^{46}$

Robert L. Kennon was also a Methodist minister. ${ }^{47}$ Born in Granville County, North Carolina in 1789 , he began his career in ministry at an early age. He moved to Alabama in 1819, purportedly because

The country was in the process of being rapidly settled, and those who went thither, generally, in their eagerness for worldly gain, lost sight of the importance of Divine institutions. It needed a powerful influence to stem the rising current of iniquity in that new country; and Mr. Kennon soon felt the obligation pressing upon him to consecrate his undivided energies to this work. ${ }^{48}$

He moved to Tuscaloosa well before Boucher, and he was held in very high regard by those that

knew him. Personally, he is also reported to have been a mild mannered and deeply spiritual individual. One contemporary recalls:

His social status was a high one. He was recognized as a man of large views, cultivated mind, and altogether of an elevated character; and he did not lower the dignity of the Christian minister, when he mingled in the innocent enjoyments of social life. All who knew him knew that he was a man of deep and ardent piety, abounding in labours, and self-sacrificing to the last degree. Cheerful and even buoyant whilst suffering from bleeding lungs, he was always a delightful companion, beloved at home, and welcomed everywhere. $^{49}$

46 JOHN QUIST, RESTLESS VISIONARIES: THE SOCIAL ROOTS OF ANTEBELLUM REFORM IN ALABAMA AND MICHIGAN 349 (1998).

471 William RuSSEll SMith, REMINISCENCES OF A LONG LIFE: HistoriCAL, POLITICAL, PERSONAL AND LiTERARY 142 (Washington, William Smith 1889).

${ }^{48}$ Robert Lewis Kennon, of the Alabama Conference, 1809 --1838, in 7 ANNALS OF THE AMERICAN PULPIT: OR, COMMEMORATIVE NotiCES OF DiSTINGUISHED CLERGYMEN OF THE METHODIST DENOMINATION IN THE UNITED

StAtes 467, 468 (William B. Sprague, ed., New York, Robert Carter \& Brothers 1861).

49 Id. at 469 (reprinting letter from H. W. Hilliard, July 10, 1859). 
It may come as no surprise that Kennon acted to help Sinclair, for his sermons "carried the understanding by force of argument, and then set the soul on fire. ${ }^{, 50}$ It seems as though the hearts of both Boucher and Kennon were on fire in this cause. Regarding the enslavement of his fellow man, Kennon at the very least subscribed to a mild form of anti-slavery ideas. In 1830 when the Alabama Colonization Society was formed in Tuscaloosa, Kennon served as vicepresident. $^{51}$

One other person, Dennis Dent, appeared on Sinclair's side in one suit. Dent offered bond in case Sinclair turned out to be a slave. We know the least of his involvement in the case, and also of his motivations. He was not a minister like Boucher and Kennon, but he was nonetheless quite an important person in Tuscaloosa at the time. ${ }^{52}$ Born in Maryland, he was later known as General Dennis Dent, because in 1836 he raised and commanded a company of volunteers in the Seminole Wars in Florida. He was a Whig and, like Kennon and Boucher, a member of the Methodist Episcopal Church. One source recalls that "He was quite successful in acquiring the favor of people by his plain and winning address, with a kind word for everybody, and his purse always open to the poor and needy. Gen. Dent frequently engaged in debate, was

$50 \mathrm{Id}$.

51 QuIST, supra note 46, at 322-23 (citing Alabama State Intelligencer, January 22, 1830); State Colonization Society of Alabama, 5 AFRICAN REPOSITORY 379-80 (February 1830); Intelligence, 6 AFRICAN REPOSITORY 178, 179 (August 1830) (listing members of the Huntsville, Alabama, auxiliary society, including James G. Birney). For further discussion of religious leaders in Kennon's Tuscaloosa, see E. Brooks Holifield, The Gentlemen Theologians: American Theology In Southern Culture, 1795-1860 218 (1978).

52 William Garrett, Reminiscences of Public Men In Alabama FOR ThiRty YeArs 159 (1872). 
sensible in his views and quite pleasant in his manner."53 Consistent with that description was the part he played in Sinclair's case: it was Dent who offered the $\$ 1000$ bond for the petition. ${ }^{54}$ His dedication to this cause must have been substantial, as must have been his trust in Sinclair, Boucher, and Kennon. Interestingly enough, Dennis Dent was a slaveowner. ${ }^{55}$ We are unable to detect how much moral discomfort Dennis Dent felt with the institution of slavery, but one explanation of his -and many others'-support of a kidnapped person's suit for freedom is respect for the law.

James Paul, Sinclair’s “owner” and opponent, was a well-known figure in Tuscaloosa. He had arrived around 1821 from Tennessee, as a tin smith and he established a small shop in town. Paul started with little, but by dint of his work ethic and also sharp dealings with Tuscaloosa residents he acquired a small fortune, some land, and then human beings. His desire to acquire land appears in a letter he wrote in 1831 to the Secretary of War, asking whether individuals might purchase property that the United States had recently acquired from Choctaws. ${ }^{56}$ A life-long bachelor, he loved his work but seems not to have much compassion for

${ }^{53} I d$.

54 The bond was required as part of a freedom suit. See Negroes and Mulattoes, Bond and Free, DIGEST OF THE LAWS OF THE State OF AlabAma 627, at 632, chap. 2, sec. 2 (Henry Toulmin ed. Cahawba, Ginn \& Curtis 1823) (“An Act for the Prevention of the Liberation of Slaves, Only in Cases Hereafter Named...”).

55 Crabb's Administrator v. Thomas, 25 Ala. 212, 215 (1854).

56 See James Paul to Secretary of War, July 29, 1831, in House DocumENTS, OTHERWISE PUBL. AS EXECUTIVE DoCumENTS: 13TH CONGRESS, 2D, DoC. No. 76, at 6 (asking whether land acquired from Choctaw Nation could be sold to individuals). 
people. ${ }^{57}$ In fact, Tuscaloosa's late nineteenth century historian recalled that Paul "had little to do with the frivolities of charity." ${ }^{, 58}$ As the man who bought Sinclair from a slaver (and therefore financially supported his detestable activities) and consistently fought against the cause of freedom, he is the villain of this tale. At any rate, the lawsuits between Paul and the two Methodists ministers set up a classic conflict of a proslavery man who sought to make money against anti-slavery religious leaders.

The remaining records do not contain the complete arguments of the parties, but it appears that Paul contended that he bought Sinclair from the Johnson brothers in good faith and for a substantial amount of money and that Sinclair was a slave. Thus it is possible that for all he knew, Sinclair's claims to freedom were false, and that he was legitimately due the labor that could be wrung from his $\$ 300$ investment. The Johnson gang could be punished by death for kdinapping, ${ }^{59}$ but perhaps Paul genuinely believed that he was entitled to payment for Sinclair. And in fact it seems that he offered to settle the case for the payment of the $\$ 300$ he spent on Sinclair. ${ }^{60}$

\footnotetext{
${ }^{57}$ SMITH, supra note 47, at 183-201 (discussing "Paul the Tinner"). See also Smith and March v. Paul, 8 Porter 503 (Ala. 1839) (affirming judgment in favor of Paul on a contract).

58 SMITH, supra note 47, at 192.

59 Digest of THE LAWS OF THE StATE OF AlABAMA, supra note 54, at 207 (1823) (making knowing selling of a free person punishable by death). Later the Alabama code also made it a crime to purchase someone knowing they were free. See Digest of the Laws of the State of Alabama 415-16, secs. 24-27 (Tuscaloosa, M.J. Shade 1843) (criminalizing knowingly holding a free person as a slave).

60 Just Reciprocity, 1 African Observer 219 n. * (October 1827).
} 
Sinclair might never have had his day in court had his plight not first come to the attention of Boucher and company. In Janaury 1827 Boucher wrote to the Mayor of Philadelphia asking for additional documentation of Sinclair's free status. ${ }^{61}$ So how, exactly, did it happen? This has proven to be one of the more evasive mysteries behind the case of Cornelius Sinclair. What little record remains is almost silent on the issue. The trial record only says that at the time of the trial, Sinclair had "lately been taken out of the possession of the said Paul and is remaining with a friend — being apprehensive — that he might have been again removed and sold into slavery.",62

Most telling, though, are the later records of correspondence between Boucher and Philadelphia Mayor Joseph Watson regarding Sinclair's legal victory. ${ }^{63}$ Watson's papers record that shortly after the announcement of the verdict in Sinclair's case, Boucher had written to inform Philadelphia's abolitionist community of the successful trial. ${ }^{64}$

However much Sinclair and his Tuscaloosan benefactors should be commended for doing their part to support the antislavery cause in this one case, it would be both inaccurate and unjust

61 Joshua Boucher to James Watson, January 17, 1827, Watson Papers, Historical Society of Pennsylvania, supra note 37 .

${ }^{62}$ Sinclair v. Paul, Tuscaloosa Chancery Docket, supra note 3, at 182 . Unfortunately the record does not indicate whether "been taken out" means that Sinclair was actually removed by Boucher and Kennon, or whether the young man escaped his captivity and fled to the two ministers, and is his actions are given a passive voice simply to have the record's language match the inferior legal status that the law placed upon him. Thus are we left unaware of who began the chain of events leading up to Sinclair's legal battle.

${ }^{63}$ Carol Wilson, Freedom at Risk: ThE KIDNAPPING OF FrEE BlaCKS IN AMERICA, 1780-1865 30 (1994) (citing letter from Boucher to Watson dated March 1827).

${ }^{64}$ James Boucher to Watson, March 23, 1827, reprinted in Smith, supra note 28, at 341-42. 
to presume that these men acted alone. The litigated liberation of Cornelius Sinclair was made possible not only by the efforts of those acting locally, but also by the collaboration of a network of antislavery activists. This network was as diverse ideologically as it was geographically, with some of its participants motivated by deep religious sentiments (Kennon and Boucher, most notably), some by concerns of political duty (like Mayor Watson), and perhaps others by a respect for the law that transcended their personal interest in maintaining the institution of slavery.

\section{The Freedom Suit}

In March of 1827, twenty months after being captured and enslaved, and nearly a year after he had been taken from Paul by Boucher, Cornelius appeared in the Circuit Court for Tuscaloosa County. Sinclair was there for a trial on a petition filed on his behalf against his purported owner. The action, titled "Petition for Freedom," was brought on Sinclair's behalf "by his next friend Joshua Boucher," tried before a local jury. The South Carolina-born and educated Judge John Gayle, Jr. who was then on the Alabama Supreme Court and was sitting as a circuit judge, presided over the trial. ${ }^{65}$

Petition for Freedom, by Cornelius Sinclair, a boy of Colour.

The primary account of the central events of Sinclair's tale is the trial record of his petition for freedom. The allegations that formed Sinclair's case are summarized in the record:

\footnotetext{
${ }^{65}$ Sinclair v. Paul, Chancery Docket, supra note 3, at 181; see DIGEST OF CASES DECIDED AND REPORTED IN THE SuPREMe Court of the State of Alabama: From 1st Alabama RePORTS to 7Th PoRTER INCLusive 1 (Mobile, R.R. Dade 1840) (listing John Gayle as justice for the third circuit); CAROL BLESER, IN JOY AND IN SORROW: WOMEN, FAMILY, AND MARRIAGE IN THE VICTORIAN SOUTH, 1830-1900 17 (1991) (discussing John Gayle and his wife, Sarah).
} 
Your petitioner Cornelius Sinclair, by his next friend, Joshua Boucher, respectfully represents to Your Honor that on or about the tenth day of August in the Year of our Lord One thousand eight hundred twenty five the said Cornelius then a resident of Philadelphia $\mathrm{P}^{\mathrm{a}}$ was decoyed by a mulatto man by the name of John Smith on board of a vessel there being in the river near the navy Yard of that city. That the said John Smith applied to your petitioner Cornelius to go on board of said Vessel and aid him in bringing away some Water Mellons \& peaches. After being on board a short time the $\mathrm{Capt}^{\mathrm{n}}$ of the Vessel forcibly seized upon him the said Cornelius and by the aid of two others forcibly thrust him him [sic] down in the Hold, where he was beat \& ironed \& where Your petitioner found three other boys ironed. That in a very short another Boy was brought and treated in like manner $\&$ then the vessel Sailed. They were afterwards landed this petitioner knows not where but was taken to the House of one Joseph Johnston who was an active participator in the whole business \& afterwards Ebenezer F. Johnston, a brother of the said Joseph, brought all of them off \& about the month of October last sold your petitioner Cornelius to one James Paul of the County of Tuskaloosa $\&$ State of Alabama and your petitioner Cornelius further represents that he has lately been taken out of the possession of the said Paul \& is remaining with a friend - being apprehensive - that he might have been again removed \& sold into slavery. Your Petitioner alledges that he is free-was born free[,] that his parents obtained their freedom previous to his being born, that they at this time reside in the City of Philadelphia, all of which your petitioner can amply prove in such manner that your Honor may require from the consideration of all of which your Petitioner prays your Honor that he your petitioner my be decreed free and released from Slavery. That he may be decreed wages for the time he has been held as a slave by said Paul and that said Paul \& all other Persons may be restrained by such process $\&$ in such penalties as to your honor shall deem meetFrom Removing or otherwise intermeddling with Your Petitioner during the pendancy of this suit \&c. And may it please Your Honor to grant unto your petitioner Cornelius such other processes \& such other relief as is applicable to his case and as to Your Honor may seem proper and consonant with Justice and your petitioner as in duty bound will ever pray \&c. ${ }^{66}$

The answer to the allegations provided by James Paul was much less detailed:

The defendant answereth and saith he does not know the facts stated in said Petition are true or false other than those stated relative to this defendant Purchasing said Boy from one Ebenezer Johnston for the sum of three hundred Dollars from which purchase this defendant claims said Boy as his Slave, and

\footnotetext{
${ }^{66}$ Sinclair v. Paul, Tuscaloosa Chancery Docket, supra note 3, at 181-82.
} 
prays that he may be returned back to his possession out of which he has been taken not without there is any other matter or thing necessary \&c. ${ }^{67}$

The trial itself took place in March of 1827, many months after the critical events themselves occurred, and as the primary source of information regarding the misfortunes that befell Sinclair before his arrival in Tuscaloosa was most likely Sinclair himself, although Alabama law did not permit testimony by people of African descent ${ }^{68}$ and thus Mayor Watson had to send affidavits and even a white man to Tuscaloosa. ${ }^{69}$ The expense of all of this was something like $\$ 450 .^{70}$ Sinclair's petition for freedom was tried and granted on the ground that he was, as the jury found "born of free parents and is himself free.",71 Thus, the issue at trial involved Sinclair's origins before the "purchase" by James Paul. It seems that a successful petition for freedom usually required the testimony of a witness who could identify the victim and attest to personal knowledge of that victim's status as a free person. ${ }^{72}$

Twelve Tuscaloosa jurors believed the account of Sinclair's life before he was sold to James Paul. After hearing the evidence, the twelve white men returned a unanimous verdict: "Cornelius Sinclair is not the property of the defendant, but was born of free parents and is

\footnotetext{
${ }^{67}$ Id. at 185 .
}

${ }^{68}$ The very first provision of the Alabama code of 1823 prohibited the use of a slave's testimony, except in criminal cases against another slave. See Negroes and Mulattos, Bond and Free, DiGEST OF THE LAWs OF THE STATE OF AlABAMA, supra note 54, at 627, sec. 1 .

${ }^{69}$ Boucher to Watson, January 17, 1827, supra note 37.

70 Just Reciprocity, 1 AFRICAN OBSERVER 219 n. * (October 1827) (mentioning that Sinclair “might have been bought for 300 dollars; the expense of his recovery was 450 dollars.”).

71 Tuscaloosa Chancery Docket, supra note 3, at 186.

72 D.S. Walker to Joseph Watson, Feb. 25, 1827, 1 AFRICAN OBSERVER 47 (May 1827). 
himself free...."73 Their verdict in Sinclair's favor was to the substantial expense of one local white man and slave-owner.

Judge Gayle, who was a slave-owner himself, ${ }^{74}$ issued the order: "It is therefore ordered, adjudged, and decreed that the said Cornelius Sinclair be set free and that he be absolved and discharged from the custody and control of the said James Paul the defendant. It is further decreed that the said defendant pay the costs of this Suit." 75

\section{Interpreting the Tuscaloosa Freedom Suit}

If this verdict comes as a shock to modern observers, we are to be forgiven. For Tuscaloosa was the capital of the state where in 1830117,000 people were owned by other people; more than one in three people in the state were enslaved. ${ }^{76}$ Looking to much more recent history, Alabama prescribed imprisonment as a penalty for the crime of interracial marriage well

\footnotetext{
${ }^{73}$ Tuscaloosa Chancery Docket, supra note 3, at 186. The jurors were William Robertson, Charles Harrell, John Hargrove, James Cartwell, Humphrey B. Rogers, Henry Pickard, Hiram Colbut, Manning Clemmons, Robert S. Foster, William Forester, Jesse Bramlett, and John W. White.

74 TheOdore Weld, AMERICAN SlaVery As It Is: TESTIMONY OF A ThOUSAND Witnesses 172 (New York, American Anti-Slavery Society 1839) (reprinting John Gayle's advertisement for a runaway slave); THE JOURNAL OF SARAh Haynsworth Gayle, 1827-1835: A Substitute FOR Social InTERCOURSE xxviii-xxix (Sarah Wiggins ed. 2013) (discussing Gayle's ownership of humans and the need to sell some of them to pay family debts); John Gayle to Sarah Gayle, July 7, 1826, in Bayne and Gayle Family Papers, Southern Historical Collections, University of North Carolina Library, volume 2, at 320 (asking for the slave Hampton to be sent to Tuscaloosa to wait on the justices because it was Gayle's turn to provide a slave for the court term).

75 Tuscaloosa Chancery Docket, supra note 3, at 186.

${ }^{76}$ http://www.census.gov/population/www/documentation/twps0056/tabs15-65.pdf http://www.archives.alabama.gov/timeline/al1801.html
} 
into the twentieth century, and it elected by the highest margin in the state's gubernatorial history a man who entered office by announcing his state's dedication to "segregation now, segregation tomorrow, segregation forever." Indeed, Sinclair won his freedom in a courtroom that was less than two miles from the very spot in which Governor Wallace stood in the schoolhouse door more than one hundred years later. Thus is it unexpected that a young, penniless, friendless person of African descent would be aided by two local men, who helped him challenge his bondage in court, and that he would win his freedom by a unanimous verdict from a jury of twelve local residents.

\section{A. The Central Tendency of Southern Slave Law}

The success of the lawsuit also tells us something about the legal system and therein lies an oddity that invites explanation. The legal system developed sophisticated rules to adjudicate claims between owners and claimants on slaves ${ }^{77}$ and to protect the property rights of owners. ${ }^{78}$ For so much about slavery, at least from the perspective of the slave, is the absence of law. Slavery required, as Justice Thomas Ruffin aptly phrased it in his 1830 opinion in State v. Mann, the "uncontrolled authority over the body" of the slave. ${ }^{79}$ For slaves had to be made to feel that

\footnotetext{
${ }^{77}$ See, e.g., ARIELA Gross, Double ChARACTER: SLAVERY AND MASTERY IN THE ANTEBELLUM COURTROOM (2000); Bonnie Martin, Slavery's Invisible Engine: Mortgaging Human Property, 76 J. S. HIST. 865 (2010).

${ }^{78}$ See e e.g., CHRISTOPHER TOMLINS, FrEEDOM BOUnd: LAW, LABOR, AND CIVIC IDENTITY IN COLONIZING ENGLISH AMERICA, 1580-1865 (2010) (discussing law's protection of slavery from Revolution to Civil War); Alfred L. Brophy, Thomas Ruffin: Of Monuments and Moral Philosophy, 87 N.C. L. REv. 799 (2009) (discussing ways that Justice Thomas Ruffin's slavery decisions in tort and criminal law protected the rights of slave-owners).

79 See State v. Mann, 13 N.C. (2 Dev.) 263, 266 (1830).
} 
they had no choice but unconditional obedience to the will of the owner. ${ }^{80}$ The end of the slavery, Ruffin forthrightly wrote, was "the profit of the master." 81

Such insights about slavery were quickly turned by abolitionists to their purposes of demonstrating the harshness of slavery. Ruffin's opinion revealed the logic of slavery and that slaves could not expect help from the legal system. ${ }^{82}$ Barely a decade later, the Mississippi Supreme Court, for instance, struck down a will in which a plantation owner left his estate to his son - who was also the child of a slave owned by the man. He had taken the son and mother to Ohio and emancipated them there, but made the mistake of returning with them to Mississippi. When he died, his intestate heirs successfully challenged the emancipation and returned the son and his mother to slavery. ${ }^{83}$

This became even truer in the wake of the Fugitive Slave Act of $1850 .{ }^{84}$ One of the most controversial parts of the Fugitive Slave Act of 1850 was the prohibition of northern courts investigating the legitimacy of the claim of a slave-owner over a purported fugitive. That is, the only inquiry permitted was the issue whether the alleged fugitive was in fact the person being sought. The alleged fugitive could not testify and other defenses, such as claims by the fugitive

\footnotetext{
${ }^{80} I d$.

${ }^{81} I d$.

82 See, e.g., Harriet Beecher Stowe, A Key to UnCle ToM’s CABIN 77 (Boston, John P. Jewett 1853).

${ }^{83}$ See Hinds v. Brazealle, 3 Miss. (2 How.) 837 (1838).

84 See, e.g., Alfred L. Brophy, “over and above there broods a portentous shadow, the shadow of the law”: Harriet Beecher Stowe's Critique of Slave Law in Uncle Tom's Cabin, 13 J. L. \& RELIGION 457, 466-68 (1995) (discussing reaction to the Fugitive Slave Act of 1850 and explaining how abolitionists thought that law abandoned enslaved people).
} 
that she was not a slave, had to be decided in the home jurisdiction of the supposed owner. ${ }^{85}$ Such lack of due process drew the special attack of opponents of the act. ${ }^{86}$ And the difficulties that Sinclair faced in Tuscaloosa illustrate why adjudication of claims of freedom by southern courts were less than satisfactory to abolitionists. The story that abolitionists told is how the law abandoned enslaved people. Law was interpreted by anti-slavery legal treatises like William Goodell's The American Slave Code in Theory and Practice, ${ }^{87}$ non-fiction memoirs like Solomon Northup's Twelve Years a Slave, ${ }^{88}$ and fiction like Harriet Beecher Stowe's Uncle Tom's Cabin, ${ }^{89}$ as setting slave-owners free from control. Law only rarely called them to account and it stacked the deck in favor of owners at almost every turn. The presumption was that all people of African descent were slaves; such presumption could only be disproven by testimony of white people, often in person. ${ }^{90}$

As abolitionists successfully indicted the legal system from the late 1830s to the Civil War, ${ }^{91}$ proslavery writers had several responses. One was that enslaved people did not deserve

\footnotetext{
${ }^{85}$ Fugitive Slave Act of 1850, sec. 6, 9 STAT.AT LARGE 462 (1850).

${ }^{86}$ See Albert J. von Frank, The Trials of ANTHONy Burns: FreEdOM AND SLAVERy IN EMERSON’s Boston 96106 (1998) (discussing critique of Fugitive Slave Act of 1850).

87 William Goodell, The American Slave Code in TheOry AND PraCtice (New York, American and Foreign Anti-Slavery Society 1853). See also WELD, AMERICAN SlaVERY As IT Is, supra note 74.

${ }^{88}$ See, e.g., Solomon Northup, Twelve YeARS A SlaVe 206 (New York, Miller, Orton \& Mulligan 1855) (1853) (mentioning that the institution of slavery permits wickedness).

89 See HARriet BeECHER Stowe, UnCle ToM's CABIN (Boston, John P. Jewett 1853) (Library of Am. ed. 1982).

90 See George M. Stroud, A Sketch OF the LAW OF Slavery 77-78 (Philadelphia, Kimber and Sharpless 1827).

91 To use Jeannine DeLombard's apt phrase, abolitionists put “slavery on trial.” See JEANNINE MARIE DELOMBARD, SLAVERY ON TRIAL: LAW, ABOLITIONISM, AND PRINT CULTURE (2007).
} 
rights. The empirical investigations of the past and the present both revealed that additional rights for enslaved people were a bad idea. This was developed by proslavery treatise writers, ${ }^{92}$ who argued that slavery was nearly ubiquitous in human history, that slavery was a natural condition of humans, and the efforts to free slaves often resulted in a demographic disasters (for the owners). They often pointed to the revolution in Haiti and to the emancipation in the British West Indies. ${ }^{93}$ Judges, too, argued that slaves must be subject to the control of their owners and that courts should not question the treatment of enslaved people by their owners. ${ }^{94}$ Another response was that enslaved people were treated well and did not need additional rights. This appeared in proslavery novels written in response to Uncle Tom 's Cabin, and also in legal treatises and pamphlets. Frequently ministers spoke about the duties owed to slaves by owners. ${ }^{95}$ One upshot of those sermons was that while slaves did not have legally enforceable rights, they were owed moral duties and that owners often abided those duties. And then there was the pseudo-empirical literature that claimed slaves were treated well. Georgia Supreme Court

92 See, e.g., ThOMAs R.R. COBb, AN INQUIRY INTO THE LAW OF NEGRO SLAVERY at 301-02 (Philadelphia, T.\&W. Johnson 1858).

93 Thomas R. Dew, Professor Dew on Slavery, in ThE Pro-Slavery ARguMEnt: As MAINTAINED By ThE Most Distinguished Writers Of The Southern States 287, 424-26 (Charleston, Walker, Richards \& Co. 1852). See also GEORGE SAWYER, SOUTHERN INSTITUTES: OR, AN INQUIRY INTO ... SLAVERY ... WITH AN ANALYSIS OF THE LAWS, HISTORY, AND GOVERNMENT OF THE INSTITUTION IN THE PRINCIPAL NATIONS, ANCIENT AND MODERN ... (Philadelphia, J.B. Lippincott 1858).

94 See, e.g., State v. Mann, 13 N.C. (2 Dev.) 263 (1830).

95 See, e.g., JAmEs Henley Thornwell, The Rights And The Duties Of MASTERs: A SERMON PREACHED AT The Dedication Of A Church, ERected In Charleston, S.C., For The Benefit And Instruction Of The COLOURED POPULATiON (Charleston, Walker \& James 1850). 
Justice Ebenezer Starnes' novel, Billy Buck: Or, The Slaveholder Abroad, compared the lives of slaves to those of free workers in England and even had an enslaved character proclaim the superiority of slavery to freedom. ${ }^{96}$ Starnes also conducted an investigation of crime in the North and South to suggest that enslaved people committed less crime than free people. William and Mary professor Thomas Roderick Dew, for instance, wrote - perhaps in a self-conscious response to David Walker - that "a happier person does not exist on the face of the globe, than the negro slave of the U. States." 97 A final, minor, response was that enslaved people had some rights. John Belton O’Neall of the South Carolina Chancery Court wrote about the (minimal) rights of slaves. $^{98}$

In the 1850 s as a robust proslavery legal literature matured, the focus was on the limited rights of enslaved people. ${ }^{99}$ In fact, they argued that the natural state of humans was slavery and, thus, the law needed - if such a thing could be imagined - to be more proslavery. ${ }^{100}$ This reached its high point in two lines of thought in Dred Scott v. Sanford. First, Chief Justice Roger Taney argued that people of African descent could not be citizens of the United States and thus silenced them in federal court in diversity cases. ${ }^{101}$ Second, Taney supported Missouri's change

\footnotetext{
${ }^{96}$ Ebenezer Starnes, The Slaveholder Abroad; Or, Billy BucK's Visit, With His Master, to ENGLAND (Philadelphia, J.B. Lippincott \& Co. 1860).

97 Dew, Professor Dew on Slavery, supra note 93, at 459.

98 John Belton O’Neall, The Negro Law of South Carolina (Columbia, John G. Bowen 1848).

99 See, e.g., COBB, supra note 92 , at 301.

${ }^{100}$ James Holcombe, Is Slavery Consistent with Natural Law?, 27 S. LIT. MESSENGER 408 (1858).

10160 U.S. (19 How.) 393, 407-17, 426-27 (1857) (discussing status of people of African descent around the time of the American Revolution and framing of the Constitution and concluding that people of African descent are not
} 
in the law that had previously allowed enslaved people to claim freedom when they traveled to a free state or territory. That is, Taney supported Missouri's constriction of the instances in which enslaved people could be freed. ${ }^{102}$ The growing proslavery doctrine in the judiciary reflects and may even be a key to gauging the growing proslavery sentiment in southern culture. But even back in the 1820 s, before the robust proslavery sentiments swept through the southern judiciary the opportunities to escape slavery were extremely limited.

Especially in Alabama. For Alabama, even more than many other slave states, made it difficult for enslaved people to claim their freedom. When a testator offered his slaves a choice of slavery or freedom, many states permitted the slave to make that choice. ${ }^{103}$ Alabama did not;

citizens of the United States). See also Alfred L. Brophy, Antislavery Women and the Origins of American Jurisprudence (review essay of Sarah N. Roth, Gender and Race in Antebellum Popular Culture (Cambridge University Press, 2014)).

10257 U.S. at 446-52 (concluding that United States federal government cannot prohibit slavery in the territories). For discussion of the increasingly restrictive approach of the Missouri Supreme Court, see Andrew Fede, Roadblocks to Freedom: Slavery and Manumission in the United States South 305-314 (2012).

103 See, e.g., COBB, AN INQUIRY INTO THE LAW OF NEGRO SLAVERY, supra note 92, at 301-02 (discussing states that permit slaves to choose freedom or slavery). But in the 1850 s states began to retreat from allowing enslaved people such choices. See, e.g., Bailey v. Poindexter's Execs., 55 Va. (14 Gratt.) 132, 1858 WL 3940 (1858); Cleland v. Waters, 19 Ga. 35, 43 (1855). Contra Thomas Dixon's Will, Rockbridge County, Virginia, Will Book 13, at 80, Virginia State Library, Rockbridge County Records (probated May 1, 1854) (providing that "Negro woman Fanny to be set at Liberty provided she is willing to go to Liberia, if she does not wish to go she shall have the privilege of choosing her own master and home.”); Arthur B. Davies’ Will, Amherst County, Virginia, Will Book 13, at 51, Virginia State Library, Amherst County Records (probated March 21, 1853) (providing that "It is my will and desire that all my slaves, fifteen in number ... shall be liberated and become invested with their freedom at my death, and for the purpose of removing them to some free state if that be lawful, or to Liberia if that shall become necessary .... 
that would have been too much a recognition of the slaves' legal authority and such provisions in a will routinely were ignored. The slaves were kept in slavery. ${ }^{104}$ When other states might construe a deed of manumission in favor of freedom, Alabama construed it narrowly. ${ }^{105}$ Where North Carolina thought that someone who had been free for thirty years was presumptively free, ${ }^{106}$ there is no parallel doctrine in Alabama. Instead, there is the presumption that people of It is my further wish that in case any of my said slaves shall of their own free will and accord prefer remaining in slavery rather than accepting freedom under the provisions of this clause, then it is my desire that they shall be permitted to choose masters amongst any of my legatees hereinafter mentioned, and thereafter to become their slaves for life."). See also BeVERLEy B. Munford, VirGiniA's AtTitude TOWARD SLAVERY AND SECESSION 120 (1909).

104 See, e.g., Carroll v. Brumby, 13 Ala. 102, 1848 WL 301 (1848); Atwood's Heirs v. Beck, 21 Ala. 590, 1852 WL 212 (1852). C $C$. CobB, AN InQuiry INTO the LAW OF Negro SlaVery, supra note 92, at 251 et seq. (discussing freedom suits); Ala. Code of 1852, sec. 2052 (printing law governing freedom suits and bonds). See also Buford v. Gould, 35 Ala. 265 (1860); Rupert v. Elston, 35 Ala. 79 (1860); Union Bank of Tennessee v. Benham, 23 Ala. 143 (1853) (slaves may use habeas corpus to challenge levy on them by creditor of their "owner"). On the hurdles to slaves asserting claims of manumission in Alabama, see Thrasher v. Ingram, 32 Ala. 645 (1858); Harris v. Plant \& Co., 31 Ala. 639 (1858); Becton v. Ferguson, 22 Ala. 599 (1853); Trotter v. Blocker, Ala. (6 Porter) 269 (1839). Alabama was something of a leader in this area; as Andrew Fede discusses, in Roadblocks to Freedom, supra note 99, at 219-225, the refusal to allow slaves to choose slavery or freedom appears to begin with Carroll v. Bumbry's

\section{Administrator.}

${ }^{105}$ See Bloodgood v. Grasey, 31 Ala. 575 (1858) (construing deed of emancipation executed in Maryland in 1787 insufficient to grant freedom to petitioners' parent and thus maintaining them in slavery); Jack et al. v. Doran's Executor, 228 (1861); Farrelly v. Maria Louisa, 34 Ala. 284 (1860).

${ }^{106}$ Stringer v. Burcham, 34 N.C. 40 (1851). Stringer is discussed in John Hope Franklin, Free Negro in North Carolina at 51 (1948). 
African descent are slaves. ${ }^{107}$ The jurisprudence of slavery was mostly concerned with such issues as protecting the rights of owners, making commercial transactions function, limiting the liability of slave-owners for the torts of their slaves. ${ }^{108}$ In short, the law of slavery was about making slavery function and the limited rights accorded slaves became even more limited over time.

B. Questioning the Boundaries of Southern Law: The Secondary Literature on the Rights of Free and Enslaved People

Then again there were some instances when the court system was used by the humble to call the mighty to account. That there were any successful suits for freedom by anyone may be surprising. But sometimes those who were freed by will or inter vivos deeds made successful claims, some whose owners had taken them to free jurisdictions successfully claimed freedom, and in a few instances so did kidnapping victims. ${ }^{109}$ And it has been on these grounds - and some other rather surprising grounds, such as the civil suits filed by free people in the pre-Civil

107 See GeOrge M. STroud, A SKetch OF THE Law OF SlaVery 77-78 (Philadelphia, Kimber and Sharpless 1827). See also LA ROY SUNDERLAND, ANTI-SLAVERY MANUAL: CONTAINING A COLLECTION OF FACTS AND ARGUMENTS ON SLAVERY (New York, S.W. Benedict $3^{\text {rd }}$ ed. 1839) (1837).

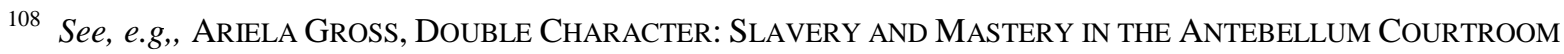
(2000); JENNy BOURnE WAHL, THE BONDSMAN's BURDEN: AN ECONOMIC ANALYSIS OF THE COMMON LAW OF SLAVERY (2002); Andrew Fede, Legal Protection for Slave Buyers in the U.S. South: A Caveat Concerning Caveat Emptor, 31 AM. J. L. HIST. 322 (1987).

109 See, e.g., Bernie JONES, FAthers OF CONSCIENCE: MiXed-RACE INHERITANCE IN THE ANTEBELLUM SOUTH (2009). Much more frequently than the instances where enslaved people were freed via will were the instances where they were devised via will. See, e.g., Stephen Davis II \& Alfred L. Brophy, "The Most Solemn Act of My Life”: Family, Property, Will, and Trust in the Antebellum South, 62 ALA. L. REV. 757 (2011). 
War years in many southern states, that one of the most dynamic debates in slavery studies in recent years is developing. The first major piece of this re-interpretation appeared about a decade ago when Melvin Ely published an expansive volume, Israel on the Appomattox, about a community of freed people who had settled on land left them by their former owner who freed them in the late eighteenth century. ${ }^{110}$ The community - surprisingly given the county's infamous closing of the public schools rather than integrate in the 1960s - was in Prince Edward County in central Virginia. Ely mined the local court records extensively to show that the community of free people had been property-owners, had engaged in trade, and had successfully used the civil and criminal court system. This introduced the controversial but important idea that even in the depths of the proslavery world of the Old South there was another world of possibilities for free people. To be sure, this was something that had been talked about before when John Hope Franklin, destined to be one of the most distinguished historians of the twentieth century, published his first book, The Free Negro in North Carolina, in $1948 .^{111}$ But Franklin's theme was the limitations of the legal system, even as he wrote about some of the ways that on rare occasions it limited the most extreme abuses of free people's human rights. ${ }^{112}$

110 Melvin Ely, ISRAEl on the APPOMATtOX: A SOUTHERn EXPERIMENT In BLACK FreEDOM FROM THE 1790S THROUGH THE CIVIL WAR (2005).

111 John Hope Franklin, The FreE NEGRo in North CAROLINA (1948). This was followed many years later by Franklin's collaboration with Loren Schweninger, In Search of the Promised Land: A Slave Family in the Old South (2006), and by Schweninger's own work on free people as property owners. See LOREN SCHWENINGER, BLACK PROPERTY OWNERS IN THE SOUTH, 1790-1915 (1990).

112 Other literature appeared around Franklin's time. See, e.g., J. Merton England, The Free Negro in Ante-Bellum Tennessee, 9 J. S. HIST. 37-58 (1943). A key point in this literature was the limitations the legal system put on free people. The high point of this literature is Ira Berlin's Slaves Without Masters: The Free Negro in the Antebellum 
Just two years ago historian Kirt von Daacke expanded Ely’s interpretation by focusing not on a single community of freed people on several hundred acres in one remote county in Virginia. von Daacke looked at all of the free people in Albemarle County, which is home to the University of Virginia. He found a similar engagement in the legal system. He also found a number of people who lived openly in defiance of Virginia's statutory requirement that newly freed people leave the state. ${ }^{113}$ That is, the legal system at the local level looked very different from what it might appear by reference to the Virginia code alone. These books pose a challenge in interpretation. Yet, one wonders about how much this tells us about the legal system. Often the story is of the failure of the ability to assert rights. Moreover, those who never are able to assert their rights at all by even making it to court do not even appear in the baseline measure. Finally, those free people who are able to successfully may have the benefit of patronage by some powerful white people. But without making any kind of claim to representativeness, the stories they tell invite speculation on what was happening.

South (1972). See also CHRISTOPHER PHILLIPS, FrEEDOM'S PORT: THE AFRICAN AMERICAN COMMUNITY OF BALTIMORE, 1790-1860 244 (1997) (discussing the literature on the rights of free people in the old South).

113 See KIRT VON DAACKe, FREEDOM HAS A FACE: RACE, IDENTITY, AND COMMUNITY IN JEFFERSON’s VIRGINIA 7779, 94 (2012) (discussing defiance of Virginia's 1806 removal state, An Act to Amend the Several Laws Concerning Slaves, 3 The Statutes at Large OF Virginia, From October Session 1792, to DeCEMber SesSion 1806 251, 252 sec. 10 (Richmond, Samuel Shepherd 1836) ). There is some question about the extent to which newly freed people were able to stay in Virginia. Some, apparently, were re-enslaved when they failed to leave. See Ted MarisWolf, Liberty, Bondage, and the Pursuit of Happiness: The Free Black Expulsion Law and Self-Enslavement in Virginia, 1806-1864 (Ph.D. dissertation, William and Mary, 2011). See also Ellen Eslinger, Free Black Residency in Two Antebellum Virginia Counties: How The Law Functioned, 79 J. S. HIST. $762-98$ (2013). 
Running parallel to such works as Ely and von Daacke are a series of studies of the legal system that are also finding some ability to assert legal claims. Judith Kelleher Schafer's Becoming Free, Remaining Free: Manumission and Enslavement in New Orleans, 1846-1862 looks deeply at the lawsuits filed by free people and by those claiming free status in New Orleans. ${ }^{114}$ The several hundred lawsuits filed in St. Louis from the 1820 s to the Civil War have had the most intense focus up to now. At least three books that examine the freedom trials are making their way to print, including Lea VanderVelde's Redemption Songs: Suing for Freedom Before Dred Scott, which shall appear this fall. ${ }^{115}$ Those works deal with the challenges of interpreting a law that was shifting towards even greater protection for the slave-owners against claims made that their "slaves" were actually free.

Martha Jones' forthcoming legal history on free people and slavery in Maryland promises the most direct engagement with the meaning of limited legal rights of free people for our understanding of legal history. For Jones looks across a series of doctrinal areas and finds that the Maryland courts often upheld the rights of free people to make and enforce contracts, travel,

114 JUdith KELLEHER SchafER, BECOMING FREE, REMAINING FrEE: MANUMISSION AND ENSLAVEMENT IN NEW ORLEANS, 1846-1862, at 59-70 (2003) (discussing freedom suits in New Orleans). See also JUDITH KELLEHER SCHAFER, SlaVery, THE CiVIL LAW, AND THE SuPREME COURT OF LOUISIANA (1993).

115 LEA VANDERVELDE, REDEMPTION SONGS: SUING FOR FREEDOM BEFORE DRED ScOTT (forthcoming 2014); see also Kelly Marie Kennington, Law, Geography, and Mobility: Suing for Freedom in Antebellum St. Louis, 80 J. SouTH. Hist. 575-604 (2014); Anne Silverwood Twitty, Slavery and Freedom in the American Confluence, From the Northwest Ordinance to Dred Scott (Ph.D. dissertation, Princeton University, 2010); David Thomas Konig, The Long Road to Dred Scott: Personhood and the Rule of Law in the Trial Court Records of St. Louis Freedom Suits, 75 UMKC L. Rev. 54-79 (2006). 
and even carry weapons. ${ }^{116}$ This demonstrates that the picture Chief Justice Roger Taney painted in Dred Scott that people of African descent were "so far inferior that they had no rights which the white man was bound to respect" ${ }^{\prime 17}$ was wrong. It represented Taney's wish and was the product of his attempt to silence enslaved people, to remove their rights. The picture that is emerging is a much finer detailed portrait than we have had before. Free people had some rights enforceable in the courts of the old South, though few, and enforcing those rights was not always easy. In many cases it seems the enforcement of the rights was dependent in part on the assistance of white benefactors, as happened in Cornelius Sinclair's case. And free people and enslaved people, too, have emerged from the shadows as legal historians demonstrate how their lived and negotiated around the brutality of slavery and the legal system that left them largely abandoned to the caprice and greed of their "owners" and creditors of their owners.

\section{Sinclair's Odyssey and The Meaning of the Rule of Law}

A nation that had only recently been created by a rebellion and was struggling with the legality of its own existence had to place a high value on the idea of law, its permanence, and its bedrock legitimacy. Slavery was justified, even as a moral negative, because it was legal, and because abolition would have entailed an unlawful deprivation of property. Here was a point where even most Northerners agreed. Whatever was to be done about the kidnapped freeman, it had to be done according to law. And therefore there must be a law that provides a remedy for the illegally enslaved to seek his freedom through the courts. When invoked, the Petition for Freedom must be taken seriously, because the law is a double-edged sword, even if the blade is

\footnotetext{
116 See, e.g., Martha Jones, Hughes v. Jackson: Race and Rights Beyond Dred Scott, 91 N.C. L. REV. 1754 (2013).

${ }^{117} 60$ U.S. (19 How.) 393, 407 (1857).
} 
much sharper on one side than the other. But the sad fact appears to be that even temporarily and wrongfully enslaved people like Sinclair needed the assistance of powerful white people to successfully assert their freedom. ${ }^{118}$

This introduces perhaps the most interesting question to the modern mind: how does a person care so much for justice and freedom that he is willing to put his time and money on the line for an African American child from Pennsylvania, and then go back to his plantation where dozens of people languish in bondage as his "property"? This invites a similar question to the one that Robert Cover posed in Justice Accused about how judges might entertain anti-slavery beliefs but still vote in pro-slavery ways. ${ }^{119}$ And in some cases anti-slavery judges still participated in the institution of slavery and supported it.

Justice William Gaston of the North Carolina Supreme Court is one who was anti-slavery - or at least acted to help enslaved people - while still participating in the institution of slavery. For he assisted his clients in drafting trusts to hold slaves in a state of quasi-slavery before he went on the bench. ${ }^{120}$ He spoke against slavery at the UNC graduation in May $1832 .{ }^{121}$ And

\footnotetext{
${ }^{118}$ Although legal historians like Lea VanderVelde in Mrs. Dred Scott (2009) and historians of slavery like Walter Johnson in River of Dark Dreams: Slavery in the Cotton Kingdom 216-17 (2013) caution us to pay attention to the agency of enslaved people in assertions of freedom, it may tragically be that in most cases enslaved claimants needed to have some white supporters or perhaps free people to fund the cases, post the bonds, hire the lawyers, and testify in court. See FEDE, ROADBLOCKS TO FREEDOM, supra note 99.

${ }^{119}$ Robert S. Cover, Justice AcCuSED: Anti-SLAVery AND the Judicial Process (1975). See aiso Jeffrey M. Schmidt, The Antislavery Judge Reconsidered, 29 L. \& HIST. REV. 797 (2011).

${ }^{120}$ See Jessica Thompson, 'Toward Freedom for All': North Carolina Quaker Legal Theory on the Trust for Manumissions, available at http://papers.ssrn.com/sol3/papers.cfm?abstract_id=2477963
} 
after ascending the bench Gaston wrote an opinion that acknowledged the human sentiments of a slave who was being beaten almost to death by his overseer. ${ }^{122}$ The slave responded with a deadly blow to the overseer and Gaston mitigated that to manslaughter from first degree murder - and this in the wake of the Nat Turner 1831 rebellion. But at Gaston's death the inventory of his estate included 160 people. ${ }^{123}$ Gaston was part of the slave-owning south, even though he also acted to discipline in limited ways the behavior of slave-owners. The spectrum of ideas and behavior for slave-owners in the south was not only free slaves or keep the shackles fastened as tightly as possible. There were shades of gray between the anti-slavery and the most pro-slavery positions, even as it was hard to maintain some ground between those two extremes.

In 1832 when a group of Whigs had asked him to come to Montgomery, Alabama, to speak William Gaston linked trade and law together with economic and intellectual progress in a letter to the Whigs:

Free as heart could wish, yet loyal to all constitutional and legal obligations, until even more by affection than by the forms of common government, and practically drawing more and more closely together by the wonder-working Steam Boat, the Canal, and the Railroad; subduing the forest to the dominion of Agriculture, and whitening ever sea with their ; advancing daily in manufacturing and mechanical skills, in arts, science, and literature; growing with unexampled rapidity in making wealth and strength; enjoying the blessings of Providence ... how could you look upon these my happy fellow citizens ... without a thrill of exultation that this was my own very native land? ${ }^{124}$

\footnotetext{
121 William Gaston, An AdDress Delivered Before the PhILANTHROPIC AND Dialectic SocIETIES AT CHAPEL HILL, N.C. (Richmond, Thomas W. White 2d ed. 1832).

122 State v. Negro Will, 18 N.C. (1 Dev. \& Bat.) 121 (1834).

123 William Gaston Inventory of Estate, 1844, Gaston Papers, North Carolina State Archives, Raleigh.

124 Gaston to Gentlemen, October 3, 1832, Gaston Papers, Wilson Library, UNC.
} 
Gaston thus placed law and constitutionalism in a matrix of values and of action that together created the United States. He illustrates how important the rule of law was to antebellum southerners, even if it might have some antislavery effects. Indeed, when Gaston spoke at Princeton University in 1835 he emphasized the importance of punishing mobs and rioters who attacked African Americans and Catholics. ${ }^{125}$ Gaston argued - in common with other Whigs that there needed to be an obedience to law. This was in contrast to the Democrats like Andrew Jackson, whom the Whigs characterized as following the dictates of passion, will, and power rather than law. ${ }^{126}$ This set up an important contrast between two visions of law in the antebellum judiciary. Where Ruffin said that owners needed uncontrolled authority over the bod of slaves (a position even he retreated from in State v. Hoover ${ }^{127}$ in 1839), others jurists, including Justice William Gaston of the North Carolina Supreme Court, thought law placed important limits on the behavior of slave-owners. In short, there was an important clash of visions of the meaning of the rule law. Where Democrats like Ruffin thought law placed few, if any, limits on slaveowners, Whigs like Gaston emphasized the limits of slave-owners power over

\footnotetext{
125 William Gaston, An AdDRESs Delivered BEFORE THE AMERICAN Whig AND CliosopHIC SOCIETIES OF THE College of New Jersey 19, 27 (Princeton, Bogert 1835). See also Alfred L. Brophy, The Republics of Liberty and Letters: Progress, Union, and Constitutionalism in Graduation Addresses at the Antebellum University of North Carolina, 89 N.C. L. REV. 1879, 1886-88 (2011).

126 See, e.g., LAWRENCE F. KOHL, THE POLITICS OF INDIVIDUALISM 33-34, 39-43, 159-62 (1989) (characterizing Jackson as hero because he was a "breaker of bonds" and as anti-hero for others, because he was someone for whom the "strongest will" was law); DANIEL WALKER Howe, WhAt Hath GOD Wrought: THE TRANSFORMATION OF AMERICA, 1815-1848, 411-45 (2008) (discussing “Jacksonian Democracy and the rule of law”).

127 See State v. Hoover, 20 N.C. (3 \& 4 Dev. \& Bat.) 500, 503 (1839); Brophy, Thomas Ruffin, supra note 78, at 814-15.
} 
fellow human beings. ${ }^{128}$ While Sinclair's case freed a wrongfully enslaved person - a rare occurrence in the old South - one should put this in the context of other criminal prosecutions of enslaved people. While those prosecutions were largely about restoring order and they instilled terror in enslaved people well beyond those on trial, they also made judgments about who merited punishment and who did not. While no one thinks those trials approached fairness for the accused, the trials spared some enslaved people from punishment, even as they helped establish order in the community by harshly punishing those with even remote involvement in the rebellion. $^{129}$

What, then, to make of Judge Gayle's role in this? He harboured some anti-slavery sentiments, it seems. Three years later, in 1830, Gayle, who was then living in Greensboro, was named a co-vice president of the newly formed Alabama State Colonization Society. ${ }^{130}$ In fact, many powerful Alabamians, including five justices of the Supreme Court, supported it. ${ }^{131}$ It is difficult to interpret precisely what support for colonization meant in terms of attitudes towards slavery. On the one hand, colonization was the only form of acceptable anti-slavery action in the south. ${ }^{132}$ The American Colonization Society struggled to gain support in Alabama because

\footnotetext{
128 See, e.g., State v. Will, 18 N.C. (1 Dev. \& Bat.) 121 (1834). For extensive discussion of Will, see Alfred L. Brophy, The Nat Turner Trials, 91 N.C. L. REV. 1817, 1872-74 (2013).

${ }^{129}$ See, e.g., Brophy, supra note 128 , at 1868-70.

130 State Colonization Society of Alabama, 5 AFRICAN REPOSITORY 379 (February 1830).

131 Id. at 379.

132 See, e.g., NEELY Young, RIPE FOR EMANCIPATION: ROCKBRIDGE AND SOUTHERN ANTISLAVERY FROM REVOLUTION THROUGH CIVIL WAR 136-45 (2010).
} 
many believed it was in favor of even more anti-slavery than colonization. ${ }^{133}$ University of Alabama professor Henry Tutweiler, a recent transplant from the Shenandoah Valley, supported it. ${ }^{134}$ Likewise, James Birney was active in colonization activity in Alabama before he abandoned the state and moved north. He ran for President on the Liberty Party in 1840. On the other hand, the core principle of colonization was the removal of enslaved people and free people of African descent from the United States. ${ }^{135}$

133 LACY K. FORD, DELIVER US FROM EVIL: THE SLAVERY QUESTION IN THE OLD SOUTH 311-12 (2009).

Meanwhile, those who would soon be strenuously arguing against slavery were saying in 1827 that colonization was not radical. See Jesse B. Harrison, The Colonization Society Vindicated to Virginia, 3 AFRICAN REPOSITORY AND Colonial Journal 193-208 (September 1827). Five years later, in the wake of the Nat Turner rebellion, Harrison rebutted Thomas Dew's proslavery essay. See [JESSE B. HARRISON], REVIEW Of THE SLAVE QUESTION (Richmond, T.W. White 1833). See also Michael O’Brien, All Clever Men Who Make Their Way: Critical Discourse IN THE OLD SOUTH 55-56 (2008) (discussing Harrison’s biography).

134 Alfred L. Brophy, The Law of the Descent of Thought: Law, History, and Civilization in Antebellum Literary Addresses, 20 L. \& Lit. 343, 349 (2008) (discussing Tutweiler's association with the American Colonization Society).

135 The latest analysis is from David Brion Davis, The Problem of Slavery in the Age of Emancipation 105-26 (2014). But this is a contentious issue and, probably because so many people were in some ways affiliated with colonization, unlikely to be resolved definitively. That is, the movement sheltered people of widely differing views, so it is hard to use membership with the American Colonization Society as a definitive gauge of attitudes towards slavery. See Matthew Spooner 'I Know This Scheme is from God:' Toward a Reconsideration of the Origins of the American Colonization Society, forthcoming SLAVERY AND ABOLITION (2014). Quist interprets the activities in Tuscaloosa as an indicator of anti-slavery sentiment. See, e.g., QuIST, supra note 46, at 322-23. Cf. Alex Lovit, “The Bounds of Habitation": The Geography of the American Colonization Society, 1816-1860 30-31 (Ph.D. Dissertation, University of Michigan, 2011) (discussing American Colonization Society in Tuscaloosa). 
But Gayle was no abolitionist. Four years after that Gayle became the governor of Alabama. Interestingly, and perhaps in illustration of the speed with which southern antislavery sentiment died, in 1835 Gayle requested that the governor of New York extradite abolitionist writer R. G. Williams for his allegedly insurrectionary publication of the Emancipator. ${ }^{136}$ As governor, Gayle clashed with President Andrew Jackson by asserted the rights of Alabama citizens to settle land reserved for Native Americans of the Creek nation. While Jackson is remembered for his brutal policy towards Native Americans, the dominant perspective among Alabama's white population was even harsher in regard to white claims to natives' land. ${ }^{137}$

Gayle was apparently not as zealously proslavery as some - and maybe even moderately anti-slavery - and in this case he presided over an outcome that was pro-freedom. So there may less to explain within him than with many, such as the anti-slavery judges whom Robert Cover studied who nevertheless participated in the legal system. But Gayle invites scrutiny as someone who worked effectively against slavery, at least at certain points in his life. Other southern

136 DeLOMBARD, supra note 91, at 51. Alabama law made it a felony to publish or distribute literature that incited insurrection. See Crimes and Misdemeanors, Digest OF THE LAWs OF THE StATE OF AlABAmA, supra note 54, at 110 sec. 55 ("Should any person distribute, circulate, or publish ... any seditious papers, pamphlets, or writing, tending to produce conspiracy, or insurrection ... among the slaves or colored population, such person, upon conviction thereof, shall suffer death.”).

137 Frank L. Owsley, Jr., Francis Scott Key's Mission to Alabama in 1833, 23 ALA. REV. 181-192 (1970); TIM ALAN

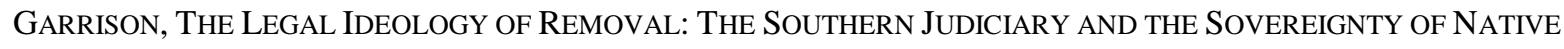
AMERICAN NATIONS 166-67 (2009) (discussing Governor John Gayle's grant of a pardon from a white man, Joseph Caldwell, who killed a Native American man, Fushatchee Yololo, on Creek lands). See also Caldwell v. State, 1 Stew. \& P. 327 (Ala. 1832). Gayle was later elected to the U.S. House of Representatives for one term, and was appointed federal district judge in 1849, in which office he served for the remaining ten years of his life. 
politicians moved from moderate anti-slavery to proslavery positions from the 1820 s and early 1830s to the late 1830s and 1840s. James McDowell of Lexington, Virginia, is another who like Gayle migrated to a proslavery position. McDowell has argued in favor of a gradual abolition plan in the Virginia legislature in 1832 in the wake of the Nat Turner rebellion, but by 1838 he was heavily criticizing abolitionists and telling Princeton students of the virtues of slavery. ${ }^{138}$ Gayle likely was following the Alabama code, which allowed freedom suits even if it made them difficult to win. And he also wanted to maintain a well-ordered society, which was a primary function of the legal system. ${ }^{139}$ A number of key members of the southern legal system,

${ }^{138}$ Compare SPEECH OF JAMES M'Dowell ... JANUARY 21, 183215 (Richmond, Thomas Whyte 1832) with JAMES MCDowell, AdDress Delivered Before the Alumni Association of THE College OF New JeRSEY, SEPTEMBER 26, 1838 34-36 (Princeton, John Bogart 1838) and Speech of James McDowell, of Virginia, on the Wilmot Proviso, Delivered in the House of Representatives, Tuesday, September 3, 1850, CONG. GLOBE, $31^{\text {st }}$ Cong, $1^{\text {st }}$ Sess., 1678, 1684. McDowell's shift from the 1832 Virginia legislative debates, where he opposed slavery because of its harmful effects, through to the debate on the Wilmot Proviso in the early 1850s, suggests something about how attitudes in the south in general shifted over that time. Though McDowell was more anti-slavery than many at the start of his career - and less proslavery at the end of it - we can see how within one person the shift towards proslavery took place. McDowell's moderate proslavery position of the Princeton address was an opposition to abolitionists and his thought that their radicalism was injuring the prospects of gradual termination. At the Wilmot Proviso debate in 1850, McDowell emphasized the ways that exclusion of slavery from the territories would subordinate the South and lead to disunion. Even there he acknowledged what seems to have been some questioning of slavery when he said that "whatever the opinions I ... entertain upon the institution of slavery in the abstract, I have never doubted for a moment that as the white and the black races now live together in the southern States, it is an indispensable institution for them both." Id. at 1678.

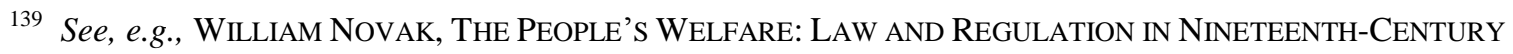
AMERICA (1996) (discussing pervasive ethic of regulation of property in pre-Civil War America); Negroes and 
including Mississippi’s attorney general, testified to the need for punishment of kidnappers. "We need no stimulus to exertion in this cause; public opinion is with us," wrote Mississippi attorney general Duncan S. Walker, ${ }^{140}$ assuring Mayor Joseph Watson of Philadelphia of "the hearty co-operation of our citizens in the pursuit and punishment of these audacious and infamous aggressors on all laws, human and divine.” Another Natchez lawyer, Richard Stockton, similarly wrote that "[p]ublic feeling is uniformly enlisted in favour of the petitioning slave, and the bar are ever ready to tender their professional services."141 One Mississippi newspaper editorialized against the kidnappers. It used the kidnappings to argue for further restrictions on the introduction of slaves from other states into Mississippi, a controversial issue at the time. But the editorial also testified to the public outrage at the kidnappings. ${ }^{142}$ Even into the 1850s, Solomon Northup recalled in Twelve Years a Slave, the local judge who freed him loathed kidnappers. ${ }^{143}$

Many other episodes of southern legal history testify, likewise, to the desire for order in slave society that would call for the punishment of kidnappers, just as it called for the legal

Mulattoes, Bond and Free, DigeST OF THE LAWS OF THE StATE OF AlABAMA, supra note 54, at 627, at 628 sec. 5 (limiting rights of slave-owners to have gatherings of slaves at their homes), 629 sec. 11 (limiting rights of slaveowners to allow their slaves to roam), 632, chap. 2 , sec. 1, (limiting emancipation of slaves), chap. 5 sec. 1 (mandating community patrol of slaves). Those were soon supplemented by acts circumscribing the rights to educate slaves in reading and writing. See Slaves, And Free Persons of Color, A DIGEST OF THE LAWS OF THE STATE OF AlabAma 397 sec. 31 (Philadelphia, Alexander Towar 1833).

140 Walker to Watson, Feb 25, 1827, in Kidnapping, AFRICAN OBSERVER 37, 47 (May 1827).

141 Stockton to Watson, May 26, 1826, in Kidnapping, AFRICAN OBSERVER 37, 42 (May 1827).

142 Natchez, in Kidnapping, 1 AFRICAN OBSERVER 37, 42-43 (May 1827).

143 NORTHUP, supra note 88, at 293. 
system to handle the criminal behavior of slaves and to channel the most extreme punishment of slaves into the legal system. ${ }^{144}$ University of Virginia law professor Henry St. George Tucker's 1844 lectures on natural law emphasized the dangers of mob rule. ${ }^{145}$ He pointed to the recent violence in Natchez, Mississippi, where a mob of local citizens ran gamblers out of town. ${ }^{146}$ "Like the fanatics who burned the heretic at the stake for the love of God, they committed the crime of murder...."147 The maintenance of order was a constant struggle in the rural south and an important theme in the fictional literature as well. Nearly two decades earlier, University of Virginia law professor George Tucker published a novel in 1825, The Valley of the Shenandoah, which explained the central role of county courts in maintaining a stable and well-ordered community. "The county courts," he wrote, "are our political sheet-anchor to keep the vessel of state steady, in all the storms of the civil faction and sudden veerings of popular caprice."148

\footnotetext{
${ }^{144}$ Brophy, The Nat Turner Trials, supra note 128, at 1874-76. See also JAMES CAMPBELL, SLAVERY On TRIAL: Race, Class, and Criminal Justice in ANTEBellum Richmond, Virginia (2008).

145 Henry St. George Tucker, A Few Lectures on Natural LaW 44 (Charlottesville, James Alexander 1844).

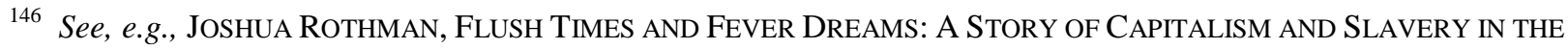
AGE OF JACKSON 157-80 (2013) (discussing the Natchez riot). Abraham Lincoln also expressed concern over the riot in his first published address. See Abraham Lincoln, The Perpetuation of Our Political Institutions: Address Before the Young Men's Lyceum of Springfield, Illinois, in LINCOLN: SPEECHES AND WRITINGS 1832-1858, at 28, 29 (Don E. Fehrenbacher ed. 1989) (January 27, 1838).

${ }^{147}$ TUCKER, supra note 145 , at 44.

1481 George Tucker, The Valley of the ShenandoAh 290 (New York, C. Wiley 1825). See also id. at 291

("We owe our tranquility, our love of order, our submission to the laws, to the circumstances that our yeomanry are people of property and commonly of education.”). 
The emphasis on law's role as a stabilizer, not an equalizer, was widespread in pre-Civil War America. New York lawyer Daniel Lord told the Yale Phi Beta Kappa Society in 1851 of the important role that lawyers served in promoting stability in society. He spoke in the wake of the Fugitive Slave Law of 1850, which was causing many to have a lack of faith in law. Lord emphasized that the role of law was to bring stability to American culture. Other Phi Beta Kappa orators at Harvard and Brown in the year following the Fugitive Slave Law, urged obedience to the law, because that was central to, they thought, civilization. ${ }^{149}$ The law, and property rights in particular, Presbyterian Minister Thomas Verner Moore told the Washington College literary societies, was central to government and to the American character. ${ }^{150}$ The rule of law meant, largely, obedience to property rights rather than some kind of equal treatment for people of African descent, of course. And therein may lie the key to understanding why the legal system

149 See DANIEL LORD, ON THE EXTRA-PROFESSIONAL INFLUENCE OF LAWYERS AND MiniSTERS: AN ORATION Delivered at New Haven, Before the Phi Beta Kappa Society of Yale College . . July 30, 1851 (New York, S.S. Chatterton 1851); TIMOTHY WALKER, THE REFORM SPIRIT OF THE DAY: AN ORATION BEFORE THE PHI Beta Kappa Society of Harvard University, July 15, 1850 (Boston, James Munroe \& Company 1850);

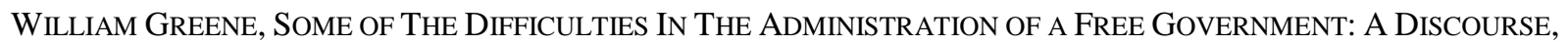
Pronounced Before The Rhode Island Alpha Of The Phi Beta Kappa Society, July 8, 1851 (Providence, John F. Moore 1851).

150 T.V. MOORE, The CONSERVATIVE ElEMENTS OF AMERICAN CIVILIZATION: AN AdDRESS BeFORE THE PHILO AND Franklin Societies of JefFerson College, CANOnsburg, PA. Delivered third of August, 185319

(Pittsburgh, J. Shyrock 1853) (arguing for importance of rights of property as part of preservation of government and national character). See also id. at 8 ("That which men talk of most, read of most, labor for most, for which they most freely lavish their time and treasure, is that which constitutes the real staple of their character, and the actual sentiments of their souls in regard to it, is the predominant philosophy of that people.”). 
so thoroughly abandoned African Americans, particularly the enslaved, while in this case affording relief - even though far too slowly and far too expensively - to Cornelius Sinclair. In fact, given that it cost perhaps $50 \%$ more to follow the legal procedure to rescue Sinclair than it would have to just purchase his freedom, one ought to ask whether this was in any way a vindication of the rule of law. Though Alabama provided by statute a way to regain freedom, ${ }^{151}$ it was costly. That cost may explain why New York passed a statute in the 1840 , while the abolitionist William Seward was governor, that authorized the governor to spend public money to recover free people from New York who were kidnapped and sold into slavery. ${ }^{152}$

But what about slave-owners, not jurists, who take action against slavery? This is yet a more difficult question from that posed by Cover, for it asks about a litigant who is anti-slavery but still engaged in the institution of slavery. Possibly this was a case of holding people in quasislavery, where an "owner" allowed enslaved people to work on their accounts and to have substantial control over their lives. ${ }^{153}$ Courts routinely tried to stop quasi-slavery, for it threatened slavery by suggesting the enslaved that they might have some, or even a lot, of freedom. There was at least one plantation in nearby Greensboro that was run on such a

151 See Negroes and Mulattoes, Bond and Free, in DigeSt OF THE LAWs OF THE StATE OF ALABAMA, supra note 54, at 627 , at 632, chap. 2 , sec. 2 (detailing requirements of a freedom suit).

152 An act more effectually to protect the free citizens of this State from being kidnapped, or reduced to Slavery, 4 Statutes at Large of the State OF New York 522, Chap. 375 (May 14, 1840) (Albany, Weare C. Little 1867). See also Paul Finkleman, The Protection of Black Rights in Seward's New York, 34 CIVIL WAR HIST. 211, 232 (1988) (discussing legacy of the statute).

${ }^{153}$ See Brophy, supra note 78, at 818-24 (discussing North Carolina Supreme Court's response to trusts holding slaves in quasi-slavery); Thompson, supra note 120 (discussing William Gaston's drafting and defense of trusts for quasi-slavery). 
principle. ${ }^{154}$ A more likely possibility is that Dent saw his role as acting as "benevolent" owner (at least in his own mind, even if not in the view of the people he "owned"); ${ }^{155}$ possibly Dent saw a distinction between people who were "lawfully" enslaved and those who were free. Or maybe he did this because he was prevailed upon by his friends, even though he harbored no antislavery sentiments.

There were literary analogs to some of those positions. In Harriet Beecher Stowe's 1856 novel Dred: A Tale of the Great Dismal Swamp one of the central characters, an heiress of a plantation in North Carolina, Cora, held enslaved people in quasi-slavery until she decided she needed to free them. ${ }^{156}$ In George Tucker's novel The Valley of the Shenandoah, the scion of a family with declining fortunes spoke about the evils of slavery. Yet that man, Edward Grayson, continued as a slave-owner because he believed that there was no better alternative. ${ }^{157}$. Grayson, perhaps a stand-in for the author's views, seems to have honestly believed he was doing right by the enslaved humans he owned. Yet, later in the novel the Grayson family's slaves were sold to pay debts left by their father, which provided at least a mild critique of the slavery. ${ }^{158}$ And the extensive sermons on duties of slave-owners to enslaved people may have

\footnotetext{
154 See G. WARd HubBs, GuARding GreEnsboro: A CONFEDERATE COMPANY In THE MAKING OF A SOUTHERN COMmuniTy 64-65 (2003) (discussing John Hartwell Cocke's plantation in Greensboro that was run by enslaved people).

155 See, e.g., THORNWELL, supra note 95.

156 See Alfred L. Brophy, Humanity, Utility, and Logic in Southern Legal Thought: Harriet Beecher Stowe's Interpretation in Dred: A Tale of the Great Dismal Swamp, 78 B.U. L. REV. 1113 (1998).

1571 TUCKER, THE VALLEY OF THE SHENANDOAH, supra note 148, at 95.

158 See, e.g., 2 id. at 196.
} 
made slavery more acceptable by making life somewhat less harsh, or at least appearing somewhat less harsh. ${ }^{159}$

There is one short story about a kidnapping of a free child, much like Cornelius Sinclair, that poses some tantalizing possibilities in terms of setting and also interpretation. The proslavery novelist Caroline Hentz, ${ }^{160}$ who taught for some years at a female seminary in Tuscaloosa, published in the 1850s the short story "Wild Jack, or the Stolen Boy." story of a free boy, Jack, who is taken from his mother's custody. The mother, who is a free person works for the president of an unnamed college, fears that he will be sold as a slave. The mother appeals to her employer, the president, and he organizes a search party. Then a neighbor, the father of the man who kidnapped the boy, puts up money to buy Jack back.

One wonders how much it is based on events in Tuscaloosa, which is home to the University of Alabama, founded in 1831 a few years after Sinclair was rescued from there. Perhaps this has nothing to do with Sinclair and is, instead, about the University's president, Basil Manly. ${ }^{162}$ It may be more about the effort of the neighbor to protect his son; there are so many different trajectories shooting through the story that it invites a lot of different

\footnotetext{
159 See, e.g., THORNWELL, supra note 95.

160 See Alfred L. Brophy, The Law of the Descent of Thought: Law, History, and Civilization in Antebellum Literary Addresses, 20 L. \& LIT. 343, 360-61 (2008) (discussing the story of the "Stolen Child").

161 Caroline Hentz, The Banished Son And Other Stories of the Heart (Philadelphia, T. B. Peterson, 1856), 47, 64 ("We have related [the story], as one of many instances of Southern kindness and humanity to a lowly racewhose feelings the Southron is too often accused of disregarding and trampling under foot.”).

162 A. JAMES Fuller, ChAPLAIN TO THE CONFEDERACY: BASIL MANLY AND BAPTIST LIFE IN THE OLD SOUTH (2000).
} 
interpretations. But maybe what it also reflects is the desire for people, even within a system of brutality like slavery to have some kind of prohibition of kidnapping. Or maybe this story simply provides a subtle response to abolitionists who charged that there was no humanity in the slave south. And that itself might explain some of the co-operation between the southern legal system and Mayor Watson. Especially in the era before comity broke down completely there may have been a sense that southern courts needed to co-operate with the return of free people and the punishment of kidnappers. ${ }^{163}$ There may have been the sense that the law prohibited kidnapping and that once the high burden of showing that someone had been kidnapped had been met, that a victim would be freed. The cost of exercising that right might be enormous; it might even be higher than the cost of purchasing freedom in the first place.

Though the handiwork of the native Southern antislavery movement can be found in many places, it has nonetheless been almost utterly deleted from modern memory. Theorists may point to a number of explanations for this: collective guilt over our ancestors' tolerance of the enslavement of our fellows, historiographical failure, or simply the difficulty required to access the records. Regardless, later events in America that loom far larger in our collective memory have worked to overshadow the nascent southern antislavery movement, as well as to seemingly diminish its ultimate significance.

There can be little doubt that by the time of the Civil War, few in the South still held equivocal views on the maintenance or abolition of slavery, or at least those who did spoke not of it publicly. Many events transpired between Sinclair's Petition for Freedom and the

163 Don E. Fehrenbacher The Dred Scott CASE: ITS SignificANCE IN LAW AND Politics 51-55 (1977) (discussing period of accommodation in which southern courts accepted freedom for slaves who traveled in free states and territories). 
Compromise of 1850 that caused the majority of the white population of the southern states to shift their personal views on slavery from an uncomfortable tolerance to a positive acceptance. Nat Turner's Rebellion in 1831 is considered a watershed moment in the history of American slavery, and not without reason. The slave rebellion generated massive panic amongst the southern white population, and by almost all accounts, hardened slavery's proponents against any suggestion of abolitionism. This came only four years after the judgment that granted Cornelius Sinclair his freedom.

In addition to the racial fears that the rebellion fueled in the slave states, ${ }^{164}$ the rapid development in the South of a cotton plantation economy that was utterly dependent upon slave labor vested in the region's white population a very powerful economic interest in maintaining the institution. As should be expected from a populace whose very presence in the newly established states had largely been driven by the hope for new economic opportunity, whatever humanitarian antislavery sentiment that existed quickly became subjugated to the desire for wealth. That the majority of the white population were not slaveholders was irrelevant; the prospect of achieving the immense wealth of their planter neighbors was incentive sufficient to affirm in their minds the desirability of the status quo.

This massive shift of Southern society to a polarized, proslavery position happened very quickly. During the 1830 s, the changes in attitudes manifested themselves in acts of the various southern state legislatures. Alabama's slave law impose numerous and draconian restrictions slaves and free blacks, including limiting on manumission via will and other forms of emancipation, prohibition of slave possession of alcoholic beverages, firearms, dogs, and other

\footnotetext{
${ }^{164}$ See, e.g., Brophy, Nat Turner Trials, supra note 128, at 1836-42.
} 
useful goods, and elimination of basic contract and property rights. ${ }^{165}$ Beyond merely further deteriorating every slave's individual rights in the southern states, these statutes ultimately rendered nearly impossible the chance of any present slave ever becoming free. Thus was Cornelius Sinclair rather fortunate that he was kidnapped when he was, for had his trial taken place ten or fifteen years later, a very different result may have obtained. Justice Thomas Ruffin's vision of law as releasing owners from liability was winning out over Justice William Gaston's vision of law as subordinating everyone, including slave-owners, to control. ${ }^{166}$ As the famous narrative of Solomon Northup demonstrated, by the 1840s it was exceedingly difficult for a free person to assert a claim to freedom. While it might be done, as Northup's eventual redemption after a dozen years showed, no one could count on being able to assert legal rights or to return from the heart of the slave-owning south.

Nonetheless, the fact remains that for a time, there existed in the South a genuine moral opposition to slavery. Cornelius Sinclair was liberated by twelve white men in Alabama, in 1827. Public opinion then really was on the side of the kidnapped child. Enslaved people were fewer, Cotton was not yet King, and Tara was a large wooden farmhouse. But something was changing, and for the worse. The later dominance of plantation society led to a wide array of

165 FORD, DELIVER US FROM EVIL, supra note 133, at 295 (summarizing changes in Alabama slave law); JAMES SEllers, SlaVery IN AlABAma 233 (1950) (summarizing Alabama law regarding slavery); DiGEST OF THE LAWS OF THE STATE OF ALABAMA, supra note 54, at 627-46 (printing Alabama code regarding slavery).

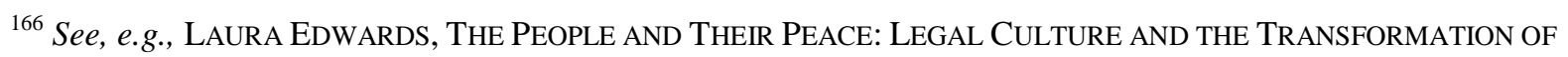
INEQUALITY IN THE POST-REVOLUTIONARY SOUTH 238-44 (2009) (interpreting breaches of the peace as issues of public concern, though recognizing that slave-owners had substantial latitude over enslaved humans and nothing that slaves were increasingly cast outside of the borders of the peace). 
efforts to justify and even to support the institution of slavery. Southern planters began a massive campaign to counter Northern abolitionists, which held sway for the time being. Slavery's days were numbered, but that was not so apparent.

Cornelius Sinclair's struggle to regain his freedom was costly; it is hard to view this as in any way a triumph of the rule of law. Yet, it is still surprising that even with assistance from local citizens and his home city that he achieved freedom. It is easily conceivable that even in 1827 he might not have achieved freedom - for Reverend Boucher mentioned in March 1827 to the Mayor of Philadelphia announcing Sinclair's successful suit that there was another kidnapped Philadelphian in a neighboring county. ${ }^{167}$ That we never hear of his freedom suggests that he, in fact, never regained it. And given James Paul's violence it is entirely possible that Cornelius might never have achieved freedom had Boucher and Kennon not acted to get him away from Paul.

One can also see how much more difficult it became to secure freedom by looking at Solomon Northup's experience along the Red River in Louisiana from 1841 to 1853 . Thanks to Hollywood and the Academy of Motion Picture Artists, ${ }^{168}$ Northup's struggle is now wellknown. Movie-goers know of Northup's kidnapping and his transportation to New Orleans and sale there, as well as the brutality of slavery and difficulty of finding anyone to assist him in getting word back to his family and supporters in New York state. The world was so dangerous that it took nearly a dozen years to get word out. It was not until a Yankee carpenter, Bass, arrived that Northup finally was able to have a letter sent home; then it took months for people in

\footnotetext{
167 James Boucher to Watson, March 23, 1827, reprinted in Smith, supra note 28, at 342.

168 Michael Cieply \& Brooks Barnes March, “12 Years a Slave” Claims Best Picture Oscar, NEW YORK TIMES
} (March 2, 2014). 
New York to take action and arrive in Louisiana to look for Northup. ${ }^{169}$ Even then if Northup's owner, Edwin Epps, had even a hour's notice of what would happen, he would likely have foiled plans laid to reclaim Northup and free him. ${ }^{170}$ The efforts they went to to free Northup were extraordinary, from collecting affidavits regarding his free status, to contacting prominent Louisiana politicians to secure introductions to local officials, to finally sending a prominent white man from Albany to Louisiana to find Northup, plead his case, and bring him home. ${ }^{171}$ Even after learning from the local sheriff that Northup was a free person, Epps want to his lawyer to seek to exercise his legal rights and to challenge Northup's claim to freedom. ${ }^{172}$

Northup's narrative shares much in common with the wildly popular novel Uncle Tom's Cabin. In fact, when Harriet Beecher Stowe published a non-fiction companion called A Key to Uncle Tom 's Cabin, she cited newspaper accounts of Northup's saga. ${ }^{173}$ And then Northup dedicated his book to Stowe. Thus it may not be surprising that Northup's account has some close parallels to Uncle Tom's Cabin. Like the fictional Uncle Tom, ${ }^{174}$ Northup began with a kind owner who then, because of debt, was forced to sell him. ${ }^{175}$ Through a series of transactions, Northup ended up - like Uncle Tom - with a ruthless owner who was motivated by

\footnotetext{
169 NORTHUP, supra note 88, at 270-72, 275 (letter home).

170 Id. at 306.

171 Id.at 304.

172 Id. at 308.

173 Stowe, Key to UnCle TOM's CABIN, supra note 82, at 420-23.

174 STOWE, supra note 89, at 19.

175 NORTHUP, supra note 88, at 105.
} 
economic considerations. ${ }^{176}$ Both Northup and Tom ended up along the Red River in Louisiana. The parallels are striking in terms of the owners and lives. Once Northup referred to Uncle Tom's Cabin to gauge how he reacted to the threat of punishment. Northup confessed that he did not have the fortitude that Uncle Tom had to resist his owner's demand that he beat other slaves. $^{177}$

Many of the critiques of slavery in Uncle Tom's Cabin have parallels in Twelve Years a Slave. Where Stowe criticizes the effects of slavery on children of slave-owners who treated slaves imperiously and thus were corrupted in their views of republicanism, ${ }^{178}$ so did Northup. ${ }^{179}$ Where Stowe emphasized the incapacity of slaves to testify in court and thus held owners accountable for abuse, ${ }^{180}$ so did Northup. ${ }^{181}$ Where Stowe explained that although some slaveowners might be humane in some instances, the law licensed all owners to be inhumane, ${ }^{182}$ that

176 Id. at 46 (a slave-trader had counted the costs of killing a slave who threatened to expose him as a kidnapper). See also id. at $61,91$.

177 Id.at 226.

178 STOWE, supra note 89, at 229-30 (discussing slave-owner's son, a child, beating an adult slave and its implications for republican government).

179 NORTHUP, supra note 88, at 261.

180 STOWE, supra note 89, at 239 (discussing abuse of Prue); id. at 440 (discussing inability to prosecute Legree for murder of Uncle Tom).

181 NORTHUP, supra note 88 , at $123,316-18$.

182 STOWE, supra note 89, at 23-24, 28 (discussing George Harris' owner); id. at 436, 440 (discussing Simon Legree); Stowe, Key to UnCle Tom's CABIN, supra note 82, at 265 ("the men better than their laws"). See also Brophy, over and above there broods a portentous shadow, supra note 83, at 468-76. 
was a key theme for Northup, too. ${ }^{183}$ Just like Simon Legree, several of Northup's owners had counted the costs and decided that they would conquer him or kill him. ${ }^{184}$ In short, the events and arguments in those two works have important parallels. They both present a powerful critique of law, which raise suspicions of the value of the rule of law in the old South. Sinclair's story is a similar parable to that of Uncle Tom's Cabin. Some well-meaning people intervened to help him, using a legal system that had a mechanism for freedom, even as its central tendency was the protection of the property rights of slave-owners. ${ }^{185}$ Sinclair's case presented a question - as college students frequently debated at the time - of whether it was better to have good people or good laws. ${ }^{186}$ The former were absolutely necessary, for the latter were lacking. The

183 NORTHUP, supra note 88, at 89 (discussing the humane owner, William Ford and Ford's need to sell Northup because of his financial problems).

184 NORTHUP, supra note 88 , at $46,61$.

185 One piece of Northup's narrative that did not quite fit into the movie version is the role of a New York statute that authorized the New York governor to use state funding for the rescue of kidnapped free people. See An Act More Effectually to Protect the Free Citizens of the State from Being Kidnapped, Or Reduced to Slavery, 4 Statutes at Large OF THE State OF NeW York 522, Chap. 375 (May 14, 1840). That statute is reprinted in the appendix to Twelve Years a Slave, Northup, supra note 88, at 323-24, along with numerous affidavits that were collected and then used to prove to the Louisiana authorities that he was, indeed, free. Id. at 325-38. 186 See, e.g., Wake Forest Euzelian Literary Society Debate Minutes, Z. Smith Reynolds Library Special Collections, Wake Forest University September 12, 1838 ("Which is the worse condition of a nation, where it has bad laws or when it has bad rulers?”); id. October 25, 1837 (“Can liberty exist without laws?”); $c f$. Washington Literary Society Minutes, March 1, 1845, Washington and Lee Library Special Collections ("Which exercises the greater influence over mankind -- the moral or the civil law?"). 
law required a lot of effort to achieve freedom. The path to freedom was long and narrow, even if in this case successful.

\section{The Return: Epilogue}

Already a system that prohibited the testimony by people of African descent was in place. Just a few years after Sinclair's suit the legal system was laughably biased against the enslaved or those claiming to be wrongfully enslaved. Sometimes an enslaved person might be heard in court, though by the time of Dred Scott Chief Justice Taney moved to place pliable plaster over the mouths of enslaved people and deny them even the opportunity to be heard in federal court sitting in diversity.

It is often said that the victors write the histories, and in the early Republic's ideological struggle between the moral acceptance of slavery and the nation's avowed commitment to individual freedom, men such as Joshua Boucher and Robert Kennon were clearly not the victors. Perhaps this is why the efforts of these men and their comrades have gone unnoticed by modern hindsight. The successful liberation of their wrongfully enslaved fellow human was a laudable accomplishment, but the fact remains that Cornelius Sinclair's Petition for Freedom was a single victorious skirmish in a war against slavery that looked like it was being lost. In fact, it was being lost, up until shortly before it was magnificently successful. Whatever ethical discomfort at the injustice of slavery was felt in the hearts of the few became utterly overwhelmed by the universal desire for personal financial gain.

This moral situation was unacceptable for Joshua Boucher, who had always taken a firm moral stance against the evils of slavery, even in the face of his more equivocally opinionated 
congregation. ${ }^{187}$ So great was the strain on his conscience that only months after his success in Sinclair's case, he requested to be transferred to the Ohio Conference, where he hoped to tend a more sympathetic flock. The leadership of the Alabama Conference refused, as the states expanding population was in great need of preachers, whereas Ohio already had sufficient ministry, but Boucher departed Tuscaloosa regardless, and was welcomed in Ohio, where he served for the next sixteen years. He later cited as his motivation for the relocation was "to get out of the hell of slavery." 188 He continued his abolitionist work in the North for the rest of his life, and died in November of 1873. There is no record of him ever returning to Alabama.

Boucher's presiding elder and ministerial comrade, Robert L. Kennon, however, did remain in Tuscaloosa for the rest of his life. He continued to preach in Methodist churches throughout Alabama until his death in January of 1838. He remained popular and highly regarded throughout his life, and is commemorated with a large marble slab that still hangs today on the wall of Tuscaloosa First United Methodist Church.

Less happy were the later fortunes of Dennis Dent. At the time of Sinclair's Petition, Dent must have been one of the wealthiest men in the community. And indeed he continued to be so for some time afterward. In addition to later raising a volunteer company to fight in Florida, Dent was elected to the state Senate in 1838 , in which he served until 1850, when he retired from public life after having becoming President of the Senate. Entering the private sector, he eventually lost most of his fortune in a disastrous business venture in Mobile called Fontaine \& Dent. Financially ruined, he died in $1860 .{ }^{189}$ His son, John Hubbard Dent,

\footnotetext{
187 SEllers \& FOSTER, HistORY OF FIRST METHODIST CHURCH, supra note 44, at 39.

188 Minutes of the CincinNATi AnNuAl CONFERENCE OF THE Methodist EpisCopal ChURCH 64 (1868).

189 GARRETt, REMINISCENCES OF PUBLIC MEN IN AlABAMA FOR THIRTY YEARS, supra note 52, at 159.
} 
graduated from the University of Alabama in 1840, and was Captain of the Confederate Army's 4th Alabama Regiment during the Civil War. ${ }^{190}$

After winning his freedom at trial, Cornelius Sinclair returned to Philadelphia. Though neither his manner of travel nor itinerary back to the North is recorded, the young man finally returned home after twenty-two months and he returned to testify against the man responsible for the hardships he had suffered. Like Odysseus returning to Ithaca, Sinclair's return was greeted with the efforts to purge the land of the traitors. Sinclair was part of prosecution of those who had kidnapped and beaten him and then sold him into slavery. "Joe Johnson" actually turned out to be one of several aliases of John Purnell, who by the time of his trial had become a notorious criminal. With the help of the testimony of Sinclair and other similar victims, Purnell was convicted for two counts of kidnapping and sentenced a four thousand dollar fine and forty-two years in prison. ${ }^{191}$ He died five years later, still incarcerated in the Walnut Street Prison. ${ }^{192}$ While Sinclair and others were safely back in Philadelphia testifying against their kidnappers, other victims were still in slavery. In addition to the group that was sent south with Sinclair, there were perhaps another sixteen - four of who may have already been slaves caught in a manner similar to Sinclair and shipped south, then marched across the land to be sold at the first opportunity. On another trip they sold some people in Rockingham County, North

\footnotetext{
190 A REGISTER OF THE OFFICERS AND STUDENTS OF THE UNIVERSITY OF ALABAMA, 1831-1901 62 (Thomas Waverly Palmer, ed. 1901).

191 Kidnapping, FREEDOM'S JoURNAL (June 22, 1827), at 3 (detailing the kidnapping and subsequent punishment); see also Kidnapping, 1 AFRICAN OBSERVER 139 (August 1827) (detailing convictions of kidnappers); Purnell, POULSON's AMERICAN DAILY ADVERTISER, June 19, 1827, at 2 (mentioning conviction and punishment). 192 Smith, supra note 28 , at 328.
} 
Carolina - and some of them were eventually re-sold in Mississippi. ${ }^{193}$ Shortly after the criminal origins of their presence in Mississippi came to light, several members of the Mississippi Bar took it upon themselves to instigate court actions to secure the freedom of the stolen children. One of these men, Duncan S. Walker, wrote to Mayor Watson to request witnesses to identify the victims, and in so doing, flatly refused any offer of monetary compensation for the prosecution of what he deemed to be a service to the public good. ${ }^{194}$

Philadelphia Mayor Joseph Watson had been actively fighting the slavers since reports of earlier kidnappings had surfaced the year before. The illegality of slavery in the North naturally required interstate transport of the victims, and because federal law enforcement power was severely limited at the time, investigation into the kidnappings and prosecution of their perpetrators necessitated a high level of communication and cooperation between the various states involved. While many contemporary commentators assume that Southern cooperation with Northern executive authorities in illegal enslavement cases must have been minimal, the case of Sinclair and his comrades proves otherwise. Mayor Watson's requests for Southern aid were met not merely with complicity, but with active cooperation in restoring the freedom of the victims. The most crucial support for these liberation efforts often came from the most influential men in slaveowning societies_-preachers, lawyers, physicians-even the governor of Mississippi, David Holmes corresponded with the northern abolitionists to hunt down the kidnapper of several free blacks who had been transported to Mississippi-the very same group

\footnotetext{
193 David Holmes to Mayor Joseph Watson, Natchez, December 23, 1826, in Kidnapping, 1 AFRICAN OBSERVER 37 , 43 (May 1827).

194 D.S. Walker to Mayor Joseph Watson, Natchez, February 25, 1827, Kidnapping, 1 AFRICAN OBSERVER 37, 47 (May 1827).
} 
that the Canon-Johnson gang kidnapped a few months after Cornelius and his comrades. ${ }^{195}$ Holmes' assistant in this case was Natchez legislator Joseph E. Davis, whose more famous brother would later become president of the Confederacy. ${ }^{196}$

Paul's violence and greed undid him. Sometime in the 1830 s or early 1840 s he moved to a plantation near the city of Columbus, Mississippi. In 1843 when his slave Aaron ran away and then was caught, Paul bound Aaron with iron shackles, then beat him and left him. Some time later Paul and his brother returned and found Aaron dead. The prosecutor in Lowndes County, Mississippi, believed they burned Aaron's body. As was recalled some decades later, Aaron disappeared mysteriously and his "supposed remains were found amidst the ashes of a burned brush-heap."197 This led to an indictment in Lowndes County, Mississippi, for murder. ${ }^{198}$ Paul then spent his fortune running from those who would try him for the murder. It is rumored that he fled to Texas to escape justice, although he was eventually brought back to Columbus. ${ }^{199}$ Some time later Paul died "at last, ruined in fortune, broken in heart and body, with a cloud of suspicion resting upon him higher and mightier than any monumental stone that money could purchase or friendship dedicate. $" 200$

\footnotetext{
${ }^{195}$ WILSON, FREEDOM AT RISK, supra note at 63 (citing “Kidnapping,” 1 African Observer 37 (May 1827)). ${ }^{196} I d$. 
It is difficult to follow what happened to the kidnapping victims. The trail goes cold on them, as it does for Cornelius Sinclair after his appearance in the Philadelphia County Court to face his kidnapper. Just as he emerged from the shadows to teach us about the limits and possibilities of law and slavery, he receded back into them. 
Table 1. Timeline of Cornelius Sinclair's Odyssey

June-August 1825

Perhaps twenty young African Americans disappear from Philadelphia

August 5, 1825

Cornelius Sinclair kidnapped in Philadelphia

August-October, 1825

Sinclair and five other kidnapped people transported by water, wagon, water again, and foot from Philadelphia and Delaware to Alabama

October 1825

Sinclair sold in Tuscaloosa

December 1825

Remaining kidnapped people travel, often by foot, to Rocky Springs, Mississippi

Joe Johnson, a chimney sweep, beaten to death by Ebenezer Johnson

Mississippi residents became suspicious and investigate Ebenezer Johnson and take possession

of the remaining kidnapped people

January 2, 1826

Letter posted to Mayor Watson in Philadelphia about the kidnapped children in Mississippi mentions Sinclair's sale in Tuscaloosa

March 6, 1826

Grand jury indictment in Philadelphia

March 10, 1826

Documents sent to Mississippi

April 17, 1826 
Joshua Boucher takes custody of Sinclair from his “owner” in Tuscaloosa

May 1826

Most of the kidnapped people sent on their way to New Orleans and then home to Philadelphia June 1826

Deposition by Samuel Scomp against kidnappers. New York Spectator, July 7, 1826, which is reprinted from Philadelphia National Gazette, June 30, 1826.

\section{October 1826}

Lawsuit filed by James Paul against Joshua Boucher for taking away his slave.

Lawsuits filed by Joshua Boucher and Robert Kennon against James Paul for defamation, saying that they had stolen his two slaves

January 17, 1827

Joshua Boucher writes Mayor James Watson pleading for Watson to send a white witness and documents about Sinclair's freedom before the March court sitting.

\section{March 23, 1827}

Kennon and Boucher wrote to Mayor Watson that Sinclair has been freed alerting him that another person kidnapped in Philadelphia is in a neighboring county.

\section{May 1827}

African Observer prints documentation about the kidnapping and reports that Sinclair is now free.

\section{June 16, 1827}

Sinclair testifies in Quarter Sessions Court in Philadelphia against one of his kidnappers, John Purnell (also known variously as Isaac Purnell, Joe Johnson, and John Smith). Purnell is sentenced to forty-two years in prison and $\$ 4000$ fine. 
1843

James Paul indicted for killing Aaron, a slave, in Lowndes County, Mississippi, and flees to Texas. 